\title{
The Disintegrin/Metalloproteinase ADAM10 Is Essential for the Establishment of the Brain Cortex
}

\author{
Ellen Jorissen, ${ }^{1,2 \star}$ Johannes Prox ${ }^{3 \star}$ Christian Bernreuther, ${ }^{4}$ Silvio Weber, ${ }^{3}$ Ralf Schwanbeck, ${ }^{3}$ Lutgarde Serneels,,${ }^{1,2}$ \\ An Snellinx, ${ }^{1,2}$ Katleen Craessaerts, ${ }^{1,2}$ Amantha Thathiah, ${ }^{1,2}$ Ina Tesseur, ${ }^{1,2}$ Udo Bartsch, ${ }^{5}$ Gisela Weskamp, ${ }^{6}$ \\ Carl P. Blobel, ${ }^{6}$ Markus Glatzel, ${ }^{4}$ Bart De Strooper, ${ }^{1,2}$ and Paul Saftig ${ }^{3}$ \\ ${ }^{1}$ Center for Human Genetics, Katholieke Universiteit Leuven and ${ }^{2}$ Department for Developmental and Molecular Genetics, Vlaams Instituut voor \\ Biotechnologie (VIB), 3000 Leuven, Belgium, ${ }^{3}$ Institut für Biochemie, Christian-Albrechts-Universität zu Kiel, D-24098 Kiel, Germany, ${ }^{4}$ Institute of \\ Neuropathology, University Medical Center Hamburg Eppendorf, 20246 Hamburg, Germany, ${ }^{5}$ Department of Ophthalmology, University Medical Center \\ Hamburg Eppendorf, 20246 Hamburg, Germany, and ${ }^{6}$ Arthritis and Tissue Degeneration Program, Hospital for Special Surgery, and Departments of \\ Medicine and of Physiology, Systems Biology and Biophysics, Weill Medical College of Cornell University, New York, New York 10021
}

The metalloproteinase and major amyloid precursor protein (APP) $\alpha$-secretase candidate ADAM10 is responsible for the shedding of proteins important for brain development, such as cadherins, ephrins, and Notch receptors. Adam $10^{-/}$mice die at embryonic day 9.5 , due to major defects in development of somites and vasculogenesis. To investigate the function of ADAM10 in brain, we generated Adam 10 conditional knock-out (cKO) mice using a Nestin-Cre promotor, limiting ADAM10 inactivation to neural progenitor cells (NPCs) and NPC-derived neurons and glial cells. The cKO mice die perinatally with a disrupted neocortex and a severely reduced ganglionic eminence, due to precocious neuronal differentiation resulting in an early depletion of progenitor cells. Premature neuronal differentiation is associated with aberrant neuronal migration and a disorganized laminar architecture in the neocortex. Neurospheres derived from Adam $10 \mathrm{cKO}$ mice have a disrupted sphere organization and segregated more neurons at the expense of astrocytes. We found that Notch-1 processing was affected, leading to downregulation of several Notch-regulated genes in Adam $10 \mathrm{cKO}$ brains, in accordance with the central role of ADAM10 in this signaling pathway and explaining the neurogenic phenotype. Finally, we found that $\alpha$-secretasemediated processing of APP was largely reduced in these neurons, demonstrating that ADAM10 represents the most important APP $\alpha$-secretase in brain. Our study reveals that ADAM10 plays a central role in the developing brain by controlling mainly Notch-dependent pathways but likely also by reducing surface shedding of other neuronal membrane proteins including APP.

\section{Introduction}

ADAM10 is a member of the large family of ADAMs (a disintegrin and metalloproteases) and is expressed in oligodendrocytes and a subset of developing neurons and brain nuclei and in differentiating gray matter (Lin et al., 2008). It is thought to be responsible for the shedding of several cell surface proteins in the brain, such as ephrins (Hattori et al., 2000; Janes et al., 2005), amyloid precursor protein (APP) (Hooper and Turner, 2002;

Received 0ct. 20, 2009; revised Feb. 15, 2010; accepted Feb. 23, 2010.

This work was supported by Deutsche Forschungsgemeinschaft Sonderforschungsbereich 415 , Interuniversity Attraction Poles Program IUAP P6/58 of the Belgian Federal Science Policy Office, DeZnit (EU-FP VI), the Center of Excellence "Inflammation at Interfaces," the Fund for Scientific Research, Flanders; the Vlaams Instituut voor Biotechnologie (VIB); and a Methusalem grant from Katholieke Universiteit (KU) Leuven and the Flemish government. M.G. is supported by Deutsche Forschungsgemeinschaft Forschergruppe 885 . E.J. was supported by Innovatie door Wetenschap en Technologie and a short-term fellowship from the European Molecular Biology Organization. C.B. was supported by National Institutes of Health Grants GM64750 and EY015719. We thank Dr. Hermans-Borgmeyer for assistance in generating the knock-out mice, Dieter Hartmann for initial help with the study, Wim Annaert for providing the anti-ADAM10 antibody, and Marlies Rusch and Véronique Hendrickx for excellent technical assistance.

*E.J. and J.P. contributed equally to this work.

Correspondence should be addressed to either of the following: Paul Saftig, Institut für Biochemie, ChristianAlbrechts-Universität zu Kiel, Olshausenstrasse 40, D-24098 Kiel, Germany, E-mail:psaftig@biochem.uni-kiel.de; or Bart De Strooper, Center for Human Genetics, VIB and KU Leuven, Herestraat 49, Box 602, 3000 Leuven, Belgium, E-mail: Bart.DeStrooper@med.kuleuven.be.

DOI:10.1523/JNEUROSCI.5221-09.2010

Copyright $\odot 2010$ the authors $\quad 0270-6474 / 10 / 304833-12 \$ 15.00 / 0$
Asai et al., 2003; Postina et al., 2004), prion protein (Vincent, 2004), and axon guidance molecules such as neuronal adhesion molecule (Hinkle et al., 2006), L1 adhesion molecule (Gutwein et al., 2003), and N-cadherin (Reiss et al., 2005). It also controls the proteolytic processing of the Notch receptor (Pan and Rubin, 1997; Wen et al., 1997; Hartmann et al., 2002; Lieber et al., 2002), which mediates lateral inhibition during neurogenesis. Adam10 knock-out mice die at embryonic day 9.5 (E9.5) due to major developmental defects, including disturbed somitogenesis, a shortened forebrain primordium, and severe vascular defects (Hartmann et al., 2002). This early lethality has precluded further investigation of ADAM10 function in the brain in vivo.

The signals transduced by the Notch receptors are crucial in cell fate decisions, both during embryonic development and in adult tissue homeostasis (Gordon et al., 2008). Signaling of the Notch receptor is dependent on three types of proteolytic events (Mumm and Kopan, 2000). After the first cleavage the heterodimeric receptor is able to interact with Notch ligands allowing a second (S2) cleavage within the Notch extracellular juxtamembrane region by ADAM proteases. The $\mathrm{S} 2$ cleavage is necessary for subsequent $\gamma$-secretase-mediated proteolysis within the transmembrane region. This allows the Notch intracellular domain (NICD) to translocate into the nucleus, thereby directly activating gene expression. Both ADAM10 and ADAM17 have been 
implicated in this S2 cleavage. Recent in vitro studies suggest that ADAM10 is absolutely required for ligand-induced Notch-1 signaling (van Tetering et al., 2009), while ligandindependent Notch-1 signaling requires ADAM17 (Bozkulak and Weinmaster, 2009).

APP ectodomain shedding is followed by further cleavage of the transmembrane fragment by the $\gamma$-secretase complex releasing an APP intracellular domain (AICD). The nature of the metalloprotease responsible for the physiologic processing of APP is not completely clear. Overexpression studies and in vitro cleavage assays indicate that ADAM9, ADAM10, and ADAM17 are able to act as $\alpha$-secretases (Buxbaum et al., 1998; Postina, 2008). Overexpression of ADAM10 in an Alzheimer's mouse model resulted in a decrease in $\beta$-amyloid deposition and cognitive deficits (Postina et al., 2004) but since transgenic overexpression of proteins creates a highly unphysiological situation, formal proof that ADAM10 is the crucial neuronal $\alpha$-secretase needs an additional loss-of-function approach.

We decided to specifically disrupt the protease in neurons using newly generated Adam10 floxed mice crossed with NestinCre transgenic mice. The neural progenitor-specific disruption of ADAM10 led to late embryonic lethality, a reduction of the ganglionic eminence (GE), and a disrupted organization of the cortical region. We analyzed the phenotype further using primary neurospheres and primary cell cultures to investigate Notch signaling and APP processing.

\section{Materials and Methods}

Generation of Adam 10 cKO mice. A mouse cosmid clone containing the $5^{\prime}$ region of the Adam10 gene with exon 2 was isolated from a 129/ola cosmid library (RZPD clone ID F11344Q2). For construction of the targeting vector, an $8.2 \mathrm{~kb} \mathrm{KpnI-PstI} \mathrm{DNA} \mathrm{restriction} \mathrm{fragment} \mathrm{of}$ Adam 10 covering exon $2,7.3 \mathrm{~kb} 5^{\prime}$ sequence, and $5.8 \mathrm{~kb} \mathrm{3}$ ' downstream sequence was subcloned into the plasmid vector pUC-18. The hygromycin B resistance gene, driven by the PGK (phosphoglycerate kinase) promoter flanked with two flippase recognition target sequences, one loxP sequence downstream of the hygromycin B resistance gene, was inserted in the NotI-ApaI site $5^{\prime}$ upstream of exon2 in intron1. A second loxP sequence was inserted into the SphI-SpeI site in intron 2. The targeting vector was linearized with $K p n \mathrm{I}$ and introduced into the embryonic stem (ES) cell line E14 $129 \mathrm{SvEv}$ by electroporation (ITL). Hygromycin B-resistant $(100 \mu \mathrm{g} / \mathrm{ml})$ colonies were screened by Southern blot analysis. Genomic DNA of ADAM10 ES cells was digested with PstI and BanI and hybridized either with a $5^{\prime}$ external gDNA probe (KpnI-BglII $767 \mathrm{bp}$ fragment), internal hygromycin probe and a $3^{\prime}$ external gDNA probe $\left(5^{\prime}\right.$ TCT TGG CAG AGC TTG AGC A 3' -5' ACA CAG GGG CTG GAA TAC TTC TA $3^{\prime}$ ) as indicated in Figure $1 A$ and displayed in Figure $1 B$. Mutated ES cell lines were microinjected into blastocysts of C57BL/6J mice. Chimeric males were obtained and mated with C57BL/6J females to transmit the modified Adam 10 alleles to the germ line. Animals carrying a null allele were obtained after breeding with transgenic females expressing a Nestin-driven Cre-recombinase. Determinations of the genotypes of the floxed mice or yolk sac of embryos were done by PCR analysis using the primers as indicated in Figure $1 A$ and displayed in Figure $1 C$. To generate Adam $10 \mathrm{cKO}$ mice, homozygous floxed mice $\left(\right.$ Adam $10^{\mathrm{Fl} / \mathrm{Fl}}$ ) were crossed with Nestin-Cre transgenic mice (Tronche et al., 1999) to obtain mice heterozygous for the floxed Adam 10 allele and hemizygous for the Nestin-Cre allele, which were then crossed with Adam $10^{\mathrm{F} / / \mathrm{Fl}}$ mice to obtain Adam10 cKO mice. Adam $10^{\mathrm{Fl} / \mathrm{Fl}}, \operatorname{Adam} 10^{\mathrm{Fl} /+}$, or Nestin-Cre; Adam $10^{\mathrm{F} / /+}$ mice were used as a control.

Western blot on brain extracts. Whole brains were taken from E12.5 embryos or postnatal day 1 (P1) mice and were lysed using cell lysis buffer ( $5 \mathrm{~mm}$ Tris base, $1 \mathrm{~mm}$ EGTA, $250 \mathrm{~mm}$ sucrose, 1\% Triton X-100). Postnuclear fractions were taken, proteins were quantified using standard BCA assay (Pierce), and $30 \mu \mathrm{g}$ protein/lane was loaded on SDS-PAGE gels and transferred to polyvinylidene difluoride membranes (Roth) to perform Western blot analysis. ADAM10 was detected using a polyclonal antiserum (B42.1) generated against the $17 \mathrm{C}$-terminal amino acid residues of ADAM10. Notch-1 fragments were detected with anti-Notch-1 mN1A antibody (Sigma) raised against the cdc10-NCR region of Notch 1 and anti-activated Notch-1 8925 (Abcam) against the NICD. N-cadherin was detected using a mouse monoclonal antibody from $\mathrm{BD}$ Transduction Laboratories (\#610920) directed against the $\mathrm{C}$ terminus of $\mathrm{N}$-cadherin. Blots were developed using the ECL detection system (GE Healthcare).

Sample preparation and immunohistochemical analysis. Embryos were fixed by immersion in $4 \%$ buffered formalin. After overnight postfixation, embryos were dehydrated in ascending ethanol concentrations and embedded in low-melting-point paraffin following standard laboratory procedures. From all paraffin blocks, $4 \mu \mathrm{m}$ sections were stained with hematoxylin and eosin (H\&E) following standard laboratory procedures and were submitted to immunostaining following standard immunohistochemistry procedures using the Ventana Benchmark XT machine (Ventana). Briefly, deparaffinated sections were boiled for 30-60 min in $10 \mathrm{~mm}$ citrate buffer, $\mathrm{pH} \mathrm{6.0,} \mathrm{for} \mathrm{antigen} \mathrm{retrieval.} \mathrm{All}$ solutions provided by Ventana. Sections were then incubated with primary antibody in 5\% goat serum (Dianova), $45 \%$ Tris buffered saline $\mathrm{pH}$ 7.6 (TBS), 0,1\% Triton X-100 in antibody diluent solution (Zytomed) for $1 \mathrm{~h}$. Followed by detection with anti-rabbit or anti-goat histofine Simple Stain MAX PO Universal immunoperoxidase polymer, or mouse stain kit (for detection of mouse antibodies on mouse sections). All secondary antibody-polymers were purchased from Nichirei Biosciences. Detection Of Antibodies was performed with an ultraview universal DAB detection kit from Ventana according to the standard settings of the machine. The counterstaining was also performed by the machine. Vasculature and connective tissue served as internal negative controls, additional negative controls included sections treated with secondary antibody only. The following primary antibodies were used: monoclonal anti-NeuN (1:50; Millipore), polyclonal anti-KI67 (1:100; Abcam), and polyclonal activated caspase-3 (1:1000; R\&D Biosystems).

BrdU labeling and immunostaining. Pregnant females were injected intraperitoneally with $\mathrm{BrdU}(20 \mathrm{mg} / \mathrm{ml})$ at $100 \mathrm{mg} / \mathrm{kg}$ body mass at gestational stage E13.5 and labeled embryos were removed at E17.5, processed, and serially sectioned. Serial sections $(6 \mu \mathrm{m})$ were used for immunohistological screening using monoclonal anti-BrdU antibody ( 1 : 100; Roche). For this, the brain sections were deparaffinized in Clear-Rite (Prosan), rehydrated, and incubated in $2 \mathrm{~N} \mathrm{HCl}$ for $20 \mathrm{~min}$ at $37^{\circ} \mathrm{C}$, neutralized in $0.1 \mathrm{~m}$ borate buffer, $\mathrm{pH} 8.5$, for $10 \mathrm{~min}$ at room temperature, rinsed twice in PBS sequentially quenched for endogenous peroxidase with $3 \%$ hydrogen peroxide for $10 \mathrm{~min}$ and blocked $30 \mathrm{~min}$ in a solution of TNB plus $5 \%$ of normal goat serum (DAKO) and incubated $\mathrm{ON}$ at $4^{\circ} \mathrm{C}$ with $0.1 \mathrm{mg} / \mathrm{ml}$ unconjugated fab fragment goat-anti-mouse IgG(Jackson ImmunoResearch) in TNB. Next day the primary antibody was applied for $1 \mathrm{~h}$ at room temperature in blocking solution, and after washing, was labeled with biotin-conjugated affinipure fab fragment goat anti-mouse IgG (1:250; Jackson ImmunoResearch) for $20 \mathrm{~min}$ and detected by streptavidin -HRP (1:200; PerkinElmer) for $20 \mathrm{~min}$ and a tyramide-based signal amplification technique (TSA, NEN-DuPont).

Generation of neurospheres. Neurospheres were generated as described previously (Reynolds et al., 1992; Tropepe et al., 1999) with slight modifications. Lateral and medial ganglionic eminences were removed from embryos, mechanically dissociated using a pipette and resulting neural stem/progenitor cells (NSC) were grown in a defined medium composed of a 1:1 mixture of DMEM and F-12 supplemented with glucose $(0.6 \%)$ (Merck), sodium bicarbonate (3 mM) (Invitrogen), B27 (2\%; Invitrogen), glutamine (2 mM) (Invitrogen), HEPES buffer (5 mM) (Invitrogen). The medium was supplemented with epidermal growth factor (EGF; 20 $\mathrm{ng} / \mathrm{ml}$; TEBU) and fibroblast growth factor-2 (FGF-2; $20 \mathrm{ng} / \mathrm{ml}$; TEBU). The cells grew in neurospheres that were passaged by mechanical dissociation after pretreatment with accutase (PAA) for $15 \mathrm{~min}$ approximately every fifth day and reseeded with a density of 100,000 cell $/ \mathrm{ml}$. The number of vital cells was determined by $0.5 \%$ Trypan blue (Invitrogen) exclusion staining. From the first passage onward, neurospheres were passaged every fifth day and stem cell self-renewal was assessed.

Differentiation and analysis of neurospheres. For immunohistochemistry of proliferating neurospheres, neurospheres cultured for $5 \mathrm{~d}$ in vitro 
A

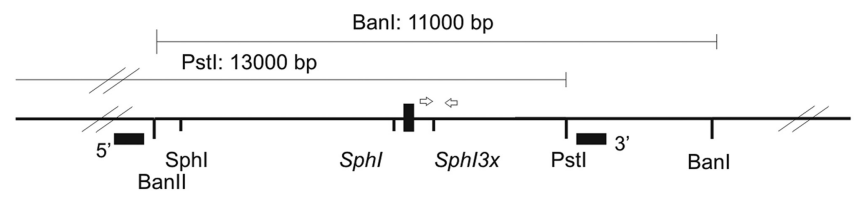

(II)

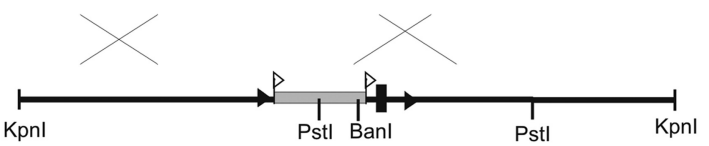

(III)

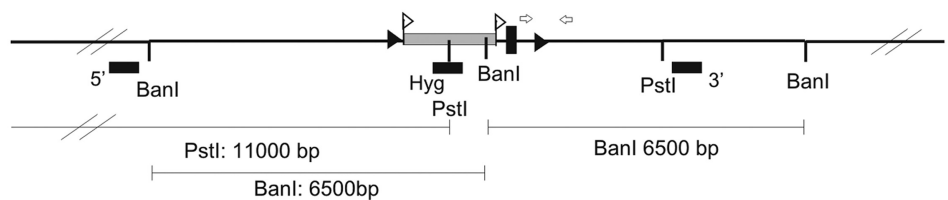

(IV)

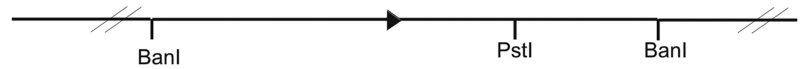

B

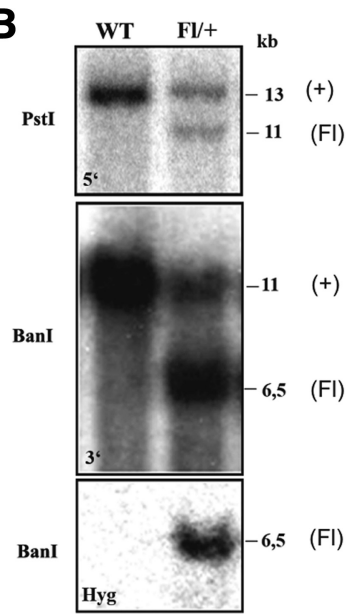

C

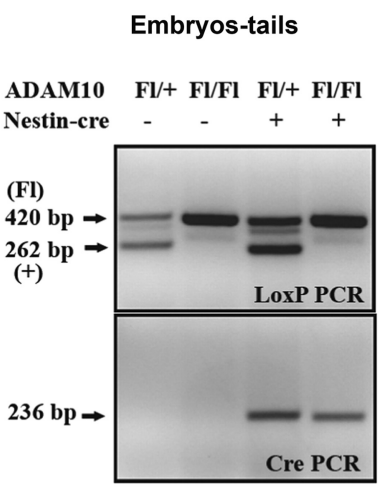

D

Brain: immunoblot

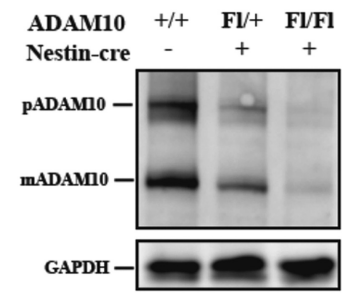

Figure 1. Generation of Adam 10 CKO mice. A, Schematic representation of wild-type Adam 10 allele (I), targeting vector (II), conditional targeted allele (floxed allele) (III), and disrupted Adam 10 allele (IV). Exon 2 is indicated as a black box. LoxP and Frt recombination sites are indicated as black arrowheads and white flags, respectively. Arrows indicate the location of the primers. The expected sizes for the indicated restriction enzyme digest fragments detected by $5^{\prime}, 3^{\prime}$, or internal hygromycin probe (Hyg) from targeted and wild-type allele are indicated below every construct with line diagrams. Positive selection marker is indicated as a gray box. $\boldsymbol{B}$, Example of Southern blot of DNA isolated from one of the selected embryonic stem cell lines, digested with the indicated restriction enzymes, and hybridized with the different probes $\left(5^{\prime}, 3^{\prime}\right.$, Hyg $)$. The fragments detected for the wild-type $(+)$ and targeted floxed (FI) Adam 10 allele are indicated. C, PCR analysis of DNA extracted from tail clips of embryos. The fragments detected for the wild-type $(+)$ and the floxed (FI) Adam 10 allele and the cre recombinase are indicated. $\boldsymbol{D}$, Western blot analysis of brain extracts from E12.5 wild-type, heterozygous, and conditional Adam 10 knock-out mice using an antibody against the $C$ terminus of ADAM10. pADAM10, Precursor of ADAM10; mADAM10, mature form of ADAM10.

were transferred and washed in PBS. Neurospheres were then fixed in $4 \%$ buffered formalin overnight. The following day, neurospheres were pelleted and put in a drop 2\% low melting agarose in PBS in a 1:1 ratio and further processed as above for paraffin embedding and immunostaining with the proper antibodies: KI67 (1:100; Abcam), Nestin (1:50; Millipore), GFAP (1:1000; Dako), activated caspase-3 (1:1000; R\&D Biosystems), doublecortin (1:400; Millipore). H\&E and Bielschowsky staining was performed according to standard procedures.

For differentiation experiments, neurospheres as a whole or dissociated into single cells with accutase (PAA) were plated at a density 500,000 cells/ml onto $15 \mathrm{~mm}$ glass coverslips coated with poly-L-ornithin (100 $\mu \mathrm{g} / \mathrm{ml}$ PBS, pH 7.3) (Sigma) in serum-free culture medium without growth factors plus $1 \%$ of FBS. Five days after plating, coverslips were fixed in $4 \%$ paraformaldehyde in PBS for $30 \mathrm{~min}$ at room temperature followed a wash in PBS. Cells were then permeabilized for $5 \mathrm{~min}$ in PBS, $\mathrm{pH} 7.3$, containing $0.1 \%$ Triton $\mathrm{X}-100$, rinsed in PBS and blocked for $1 \mathrm{~h}$ in PBS containing 5\% donkey serum (Sigma). After blocking, coverslips were incubated with anti-MAP-2c mouse monoclonal (1:400; Sigma) and anti-GFAP rabbit polyclonal (1:600; DAKO) antibodies diluted in PBS containing 5\% serum for $1 \mathrm{~h}$. Coverslips were then rinsed in PBS, pH 7.3, containing $0.1 \%$ Triton X-100 and subsequently incubated in the appropriate Alexa (Invitrogen) secondary antibodies for $1 \mathrm{~h}$. Coverslips were rinsed three times in PBS. Separate coverslips (from similar culture conditions) were used for oligodendrocyte staining. Coverslips were incubated in anti-CNPase mouse monoclonal antibody (1:1000; Sigma) in PBS containing 5\% of donkey serum $1 \mathrm{~h}$. Then, the coverslips were rinsed and subsequently incubated in secondary Alexa (Invitrogen) antibody. Cultures were counterstained with 4 ',6-diamidino-2-phenylindole $(10 \mu \mathrm{g} / \mathrm{ml}$ in $\mathrm{H}_{2} \mathrm{O}$; Roche).

Quantitative RT-PCR. RNA was extracted out of whole brains taken from P1 control $(n=5)$ and Adam $10 \mathrm{cKO}(n=3)$ animals using the NucleoSpin RNAII kit (Macherey Nagel). Two micrograms of RNA was reverse transcribed using the RevertAid first-strand cDNA synthesis kit (Fermentas). Expression levels of Hes1, Hes5, Heyl, and Hey2 were determined by real-time PCR analysis of $0.5 \mu \mathrm{l}$ of cDNA on a $7900 \mathrm{HT}$ fast real-time PCR system using the TaqMan gene expression assays-on-demand system and TaqMan universal PCR master mix (all Applied Biosystems; assay numbers Mm00468601_m1, Mm00439311_g1, Mm00468865_m1, and Mm00469280_m1, respectively) in $10 \mu \mathrm{l}$ reaction volumes. The expression levels were normalized against glyceraldehyde 3-phosphate dehydrogenase using the $\Delta \Delta \mathrm{Ct}$ method, and mean expression of the wild-type (WT) animals was set to $100 \%$.

Immune blot analysis of APP processing in primary neuronal cultures. Primary neuronal cultures were generated from trypsinized brain obtained from 14-d-old embryos. Neurons were resuspended and plated on cell culture dishes (Nunc) precoated with $1 \mathrm{mg} / \mathrm{ml}$ of polyL-lysine (Sigma) and incubated in neurobasal medium (Invitrogen) as described previously (Annaert et al., 1999). Proliferation of nonneuronal cells was prevented by adding $5 \mu \mathrm{M}$ cytosine arabinoside. Three- to five-day-old mouse primary neuronal cultures in neurobasal medium were incubated with 10-folddiluted Semliki Forest Virus (SFV) expressing the pSFV-1 plasmid bearing APP-WT. Cultures were incubated for $1 \mathrm{~h}$ at $37^{\circ} \mathrm{C}$ to allow entry of the virus, followed by incubation in conditioned medium in the absence of virus (for $2 \mathrm{~h}$ ). Medium was collected for $5 \mathrm{~h}$. Cells were rinsed twice with ice-cold PBS and lysed in $1 \%$ Triton, and postnuclear fractions were isolated by centrifugation at $10,000 \times g$ for 15 min at $4^{\circ} \mathrm{C}$. Proteins were quantified by using a standard Bradford assay (Pierce) and $30 \mu \mathrm{g}$ of proteins per lane was loaded on Bis-Tris SDS-PAGE gels (Invitrogen) and transferred to nitrocellulose membranes for Western blot detection for the indicated proteins. Polyclonal antibody B63 was used to detect APP-FL and C-terminal fragments (CTFs) (De Strooper et al., 1998; Annaert et al., 1999) in the cell extracts and 6E10 (Covance) and neo-epitope sAPP $\beta$ antibody (Covance) for $\operatorname{sAPP} \alpha, \mathrm{A} \beta$, and $\operatorname{sAPP} \beta$, respectively, in the media. Levels of $\alpha$ - and $\beta$-cleaved carboxy-terminal stubs and secreted sAPP and total A $\beta$ were normalized to the level of expression of APP holoprotein from the cell extracts. 
Table 1. Progenies of crosses of Adam $10^{\mathrm{Fl} / \mathrm{FI}}$ with Nestin-Cre; Adam10 ${ }^{\mathrm{Fl} /+}$

\begin{tabular}{|c|c|c|c|c|c|c|}
\hline \multirow[b]{3}{*}{ Age } & \multirow[b]{3}{*}{ Total $n$} & \multicolumn{5}{|c|}{ Genotype $(n)$} \\
\hline & & \multicolumn{2}{|c|}{$\mathrm{Fl} /+$} & \multicolumn{2}{|c|}{$\mathrm{Fl} / \mathrm{FI}$} & \multirow{2}{*}{$\begin{array}{l}\text { Adam10 } \\
\text { Nestin-Cre }\end{array}$} \\
\hline & & - & + & - & + & \\
\hline E12.5 & 62 & 6 & 20 & 21 & 15 & \\
\hline E15.5 & 110 & 24 & 28 & 33 & 25 & \\
\hline E17.5 & 108 & 26 & 39 & 18 & 25 & \\
\hline P1 & 72 & 16 & 23 & 27 & 6 & \\
\hline
\end{tabular}

Measurement of $A \beta$ species and immune blot analysis. $\mathrm{A} \beta_{40}$ and $\mathrm{A} \beta_{42}$ were measured via ELISA1-40 and ELISA1-42. Ninety-six-well plates were coated with monoclonal antibodies either JRF/cA $\beta_{40} / 28$ or JRF/ $\mathrm{cA} \beta_{42} / 26$ (Mathews et al., 2002) at $1.5 \mu \mathrm{g} / \mathrm{ml}$ in coating buffer containing the following (in $\mathrm{mM}$ ): 10 Tris, $10 \mathrm{NaCl}$, and $10 \mathrm{NaN}_{3}, \mathrm{pH} 8.5$, overnight at $4{ }^{\circ} \mathrm{C}$. The next day, plates were blocked in $0.1 \%$ casein in PBS for $4 \mathrm{~h}$ at RT to reduce nonspecific binding. Standards and conditioned medium (undiluted for $\mathrm{A} \beta_{42}$ and $1 / 5$ diluted for $\mathrm{A} \beta_{40}$ ) together with the detection antibody huA $\beta_{25}$-HRPO (Vandermeeren et al., 2001) were loaded into triplicate wells for ELISA and incubated overnight at $4^{\circ} \mathrm{C}$. ELISA plates were developed with $\mathrm{TMB} / \mathrm{H}_{2} \mathrm{O}_{2}$ substrate (Pierce) according to the manufacturer's specifications. The reaction was stopped with $2 \mathrm{~N} \mathrm{H}_{2} \mathrm{SO}_{4}$ and the plates were read on Envision Alphascreen (PerkinElmer) at 450 nм. The different $\mathrm{A} \beta$ species were analyzed by urea-based A $\beta$ SDS-PAGE and immune blot (Wiltfang et al., 2002) using 82E1 (Demeditec Diagnostics), a monoclonal antibody specific for the $\mathrm{N}$ terminus of $\mathrm{A} \beta$. Signals were detected using ECL chemiluminescence. The individual A $\beta$ species were normalized to the level of expression of APP holoprotein from the cell extracts.

Statistical analysis. Statistical significance was calculated by Student's $t$ test using Microsoft Excel software. Error bars indicate the mean \pm SD of the mean. $p$ values are as follows: ${ }^{*} p<0.05,{ }^{* *} p<0.01,{ }^{* * *} p<0.001$.

\section{Results}

\section{Generation of neural progenitor cell-specific Adam10} conditional knock-out mice

To circumvent the early embryonic lethality of Adam $10^{-1-}$ mice, we used the Cre/loxP recombination system to restrict ADAM10 inactivation to the CNS (Fig. 1A). The Adam 10 gene was targeted conditionally with loxP sequences flanking exon $2\left(\right.$ Adam $\left.10^{F l}\right)$. Successful targeting was confirmed by Southern blot (Fig. $1 B$ ). Homozygous floxed Adam $10^{F / F l}$ mice and the Adam $10^{F / /+}$ hemizygous mice were viable and fertile and genotypes of tail-clips were determined by PCR (Fig. 1C). We then crossed Adam $10^{F l}$ mice with Nestin-Cre transgenic mice, in which Cre is expressed in neural precursor cells under the control of the Nestin promoter (Tronche et al., 1999), to generate a neural progenitor cell (NPC)-specific Adam10 cKO mouse. Expression of Cre transcripts in Nestin-cre transgenic mice begins at E9.0 in the spinal cord and the forebrain-midbrain junction and then extends to the entire CNS by E10.5 (Yang et al., 2004). The expression of Cre in the neural progenitor cells localized in the ventricular zone (VZ) was demonstrated previously (Graus-Porta et al., 2001). Western blotting established strongly decreased levels of ADAM10 protein in total brain extracts of Adam $10 \mathrm{cKO}$ mice (Fig. 1D), with a very low residual expression level likely caused by nonneuronal cells.

\section{ADAM10 deletion in CNS leads to late embryonic lethality with intracranial hemorrhages}

We intercrossed Nestin-Cre; Adam $10^{F / 1+}$ with Adam $10^{F / F l}$ animals. We analyzed 72 pups from birth until the time of weaning (Table 1). Only six (8.3\%) homozygous Adam 10 floxed null mutants that survived $>12 \mathrm{~h}$ were observed, indicating late embry- onic and perinatal lethality of the mice. Macroscopically these cKO embryos did not display gross abnormalities except for intracranial hemorrhages (Fig. 2A).

\section{Reduction of the ganglionic eminence and disrupted organization of the cortical region in the absence of ADAM10 in the CNS}

We examined serial coronal brain sections of the Adam $10 \mathrm{cKO}$ and littermate control brains at different developmental stages between E12.5 and E17.5 by hematoxylin-eosin costaining (Fig. $2 B)$. The cerebral cortex was disorganized from E15.5 onward (Fig. $2 B i, B j, B o, B p$ ) with the exception of the upper cortical layer. The boundary between the intermediate zone (IZ), a region in which cells have undergone final mitosis and initiate migration, and the VZ, in which proliferating neuroepithelial cells reside, had disappeared. The GE in the cKO mutants also appeared to be smaller at E12.5-E15.5 (Fig. 2 $B e, B f, B k, B l$ ), a phenotype that became more apparent by E17.5 (Fig. $2 B q, B r$ ). Furthermore, the cortical region and GE displayed severe cell loss (a diminished cell number) at E17.5 (Fig. $2 \mathrm{Bp}, \mathrm{Br}$ ). These findings suggest that loss of ADAM10 disrupts the cortical organization and impairs the normal development of the GE.

The development of neurons in the embryonic brain is a complex cellular and molecular mechanism. It starts at approximately E11 with the birth of new neurons from stem cell precursors, a process called neurogenesis, and continues through E17 compromising 11 cell cycles (Caviness et al., 1995; McConnell, 1995). During early neurogenesis, very few progenitor cells in the neuroepithelium exit the cell cycle to become postmitotic neurons, while the vast majority of progenitor cells re-enter the cell cycle after mitosis, resulting in an expansion of the neural progenitor population in the ventricular zone. As neurogenesis progresses, a fraction of neural progenitor cells complete their final mitosis, differentiate into postmitotic neurons and migrate from the ventricular zone into the cortical plate, forming an "inside-out" gradient of maturation. This process is guided by radial glial fibers (Angevine and Sidman, 1961; Rakic, 1988; Hatten, 1990; Mission et al., 1991; Hatten, 1993). A massive neuronal loss in the brain and a disturbance of the lamellar composition of the neocortex can occur via several possible mechanisms, such as the following: (1) premature differentiation of progenitor cells, (2) decreased proliferation, (3) increased apoptotic cell death, or (4) cortical migration defects.

\section{Increased neuronal differentiation in Adam10 cKO brains}

To assess neuronal differentiation in the Adam $10 \mathrm{cKO}$ and control brains, we performed immunostaining for $\mathrm{NeuN}$, a marker for postmitotic neurons, at E12.5, E15.5, and E17.5 (Fig. 3A). At E12.5 there was no difference in the pattern of the NeuN immune-reactive neurons of the Adam $10 \mathrm{cKO}$ mice compared with controls (Fig. 3Aa-Af). At E15.5 more postmitotic neurons labeled by NeuN were found in the GE and the neocortex of the Adam $10 \mathrm{cKO}$ (Fig. $3 \mathrm{Ag}-\mathrm{Al}$ ). The ventricular zone, which consists of NeuN-negative progenitor cells in the control, contained also postmitotic neurons in the Adam $10 \mathrm{cKO}$ (Fig. $3 A i, A j$ ). However, at E17.5 the number of NeuN-positive cells of the cortex and the GE had decreased in Adam $10 \mathrm{cKO}$ (Fig. 3Am-Ar). Together, these observations point toward a premature differentiation of neural progenitor cells into postmitotic neurons in the absence of ADAM10 resulting in an early depletion of the neural progenitor population. 
A
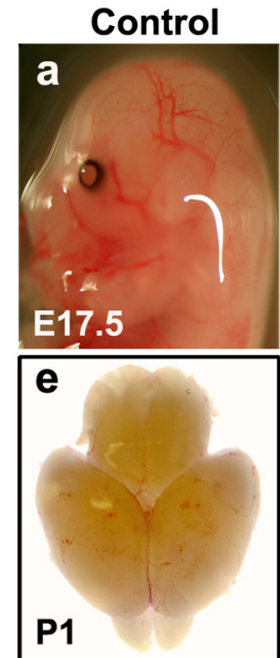

B
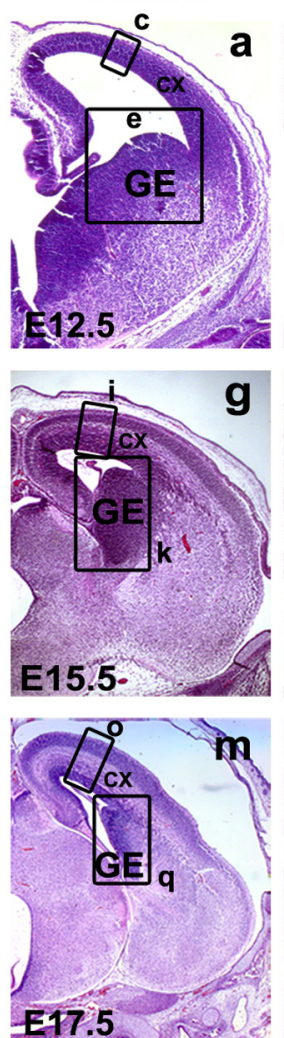

ADAM10 cKO
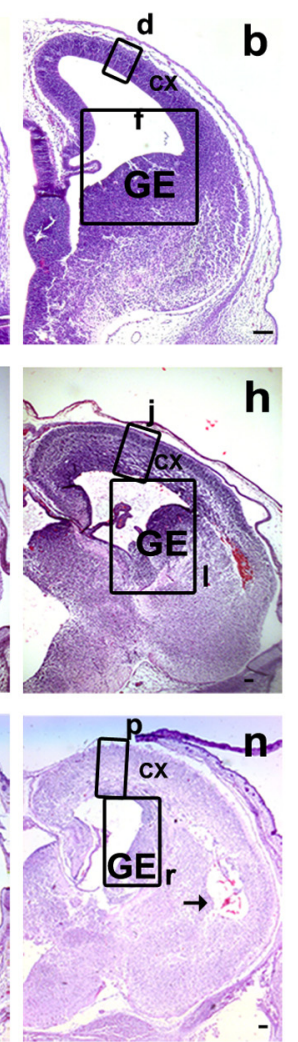

ADAM10 cKO
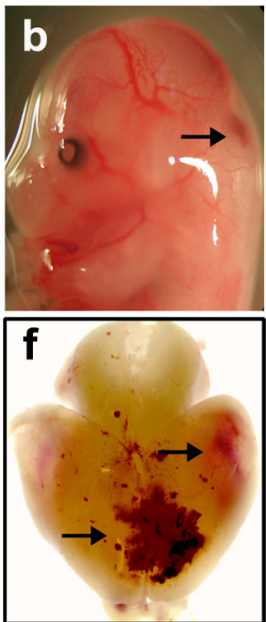

Control
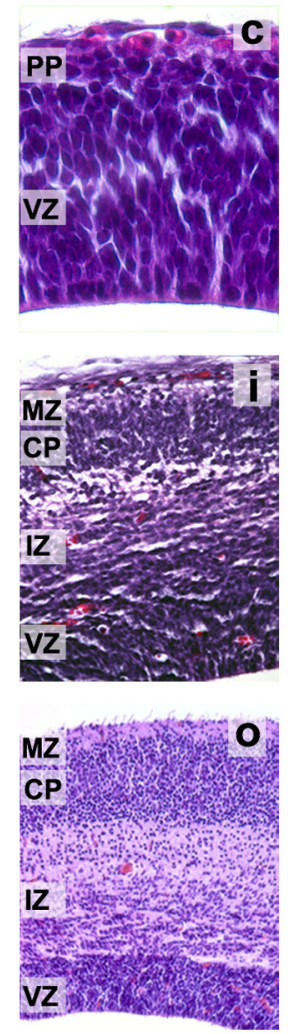
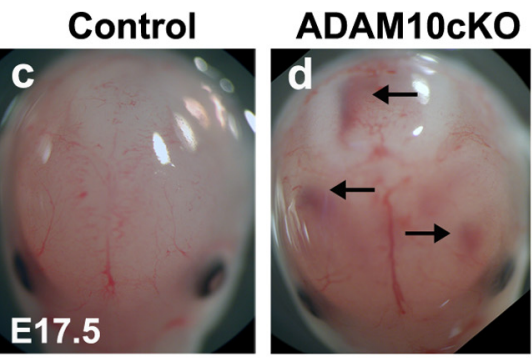

ADAM10 cKO

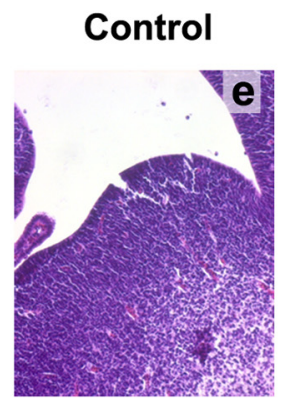

ADAM10 cKO
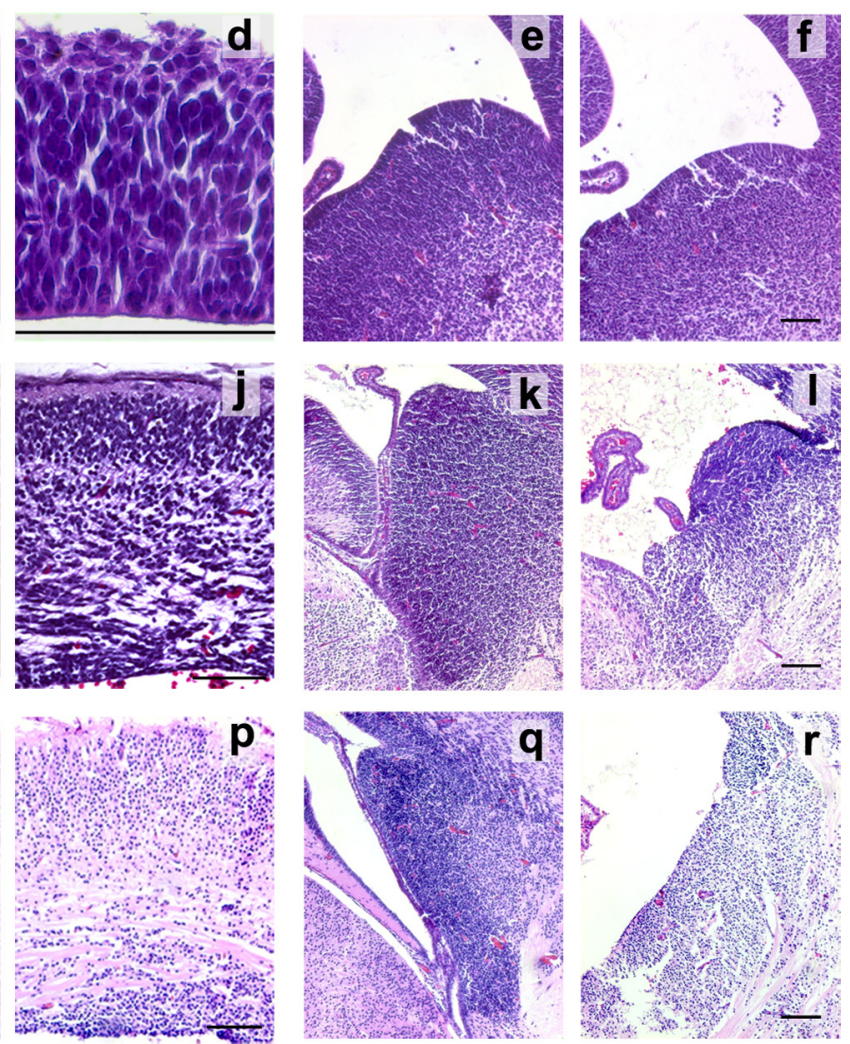

Figure 2. Histological analysis of control and Adam 10 cKO mice at different developmental stages. $A$, Lateral and coronal view of control and Adam 10 cK0 embryos at E17.5 and P1. Showing intracranial hemorrhages in the $\mathrm{KKO}(\boldsymbol{b}, \boldsymbol{d}, \boldsymbol{f}$, indicated by arrows). $\boldsymbol{B}$, Serial coronal sections at E12.5, E15.5, and E17.5 of Adam 10 cKO and littermate controls were stained with hematoxylin and eosin $(\boldsymbol{a}-\boldsymbol{r}) \cdot \boldsymbol{a}, \boldsymbol{b}$, Coronal brain sections of control and $\mathrm{Adam} 10 \mathrm{CKO}$ at E12.5. $\boldsymbol{c}-\boldsymbol{f}$, Under higher magnification, there was no difference in the cortex $(\boldsymbol{c}, \boldsymbol{d})$ formation, however the size of the GE $(\boldsymbol{e}, \boldsymbol{f})$ was slightly reduced in the $\mathrm{KK} 0$ compared with littermate controls. $\boldsymbol{g}, \boldsymbol{h}$, Coronal brain sections of control and $A d a m 10 \mathrm{cKO}$ at E15.5. The GE was prominent in the control but much less in the $A d a m 10$ cKO $\boldsymbol{i}, \boldsymbol{j}$, Higher-power views of the boxed areas in $\boldsymbol{g}$ and $\boldsymbol{h}$ showing disruption of the cortical layering, with an indistinct boundary between the VZ and the IZ in the Adam 10 cKO. $\boldsymbol{k}, \boldsymbol{I}$, Higher-power views of the GE region boxed in $\boldsymbol{g}$ and $\boldsymbol{h} . \boldsymbol{m}, \boldsymbol{n}$, Coronal brain sections of control and Adam 10 CKO at E17.5. The arrow in $\boldsymbol{n}$ indicates the disruption of the subcortical region of the temporal lobe in the cKO brain. $\boldsymbol{O}, \boldsymbol{p}$, Higher-power views of the cortical region boxed in $\boldsymbol{m}$ and $\boldsymbol{n}$ showing a cortical atrophy and a disrupted laminar organization, with an indistinct boundary between the cortical layers in the Adam 10 cKO brain. $\boldsymbol{q}, \boldsymbol{r}$, Higher-power view of the GE region boxed in $\boldsymbol{m}$ and $\boldsymbol{n}$ showing a severely reduced GE in the Adam 10 cKO. Scale bars, $100 \mu \mathrm{m}$.

The role of ADAM10 in neuronal migration during neuronal development

Bromodeoxyuridine (BrdU) birth dating was used to examine whether the abnormalities in cortical layering reflected abnormal neuronal migration. Neurons were labeled at E13.5 and appeared more brightly stained at E17.5 in the Adam10 cKO than in the control brains (Fig. 3Bb). This indicated that neurons had exited the cell cycle more early following the pulse in the cKO brains than in the wild-type brains, thereby retaining all of the incorporated BrdU. (Fig. 3, compare $B b$ to $B a$ ). This observation was in agreement with the NeuN immunostaining in Figure $3 A$. The labeled cells in the control brain were localized mostly in the 
A

Control
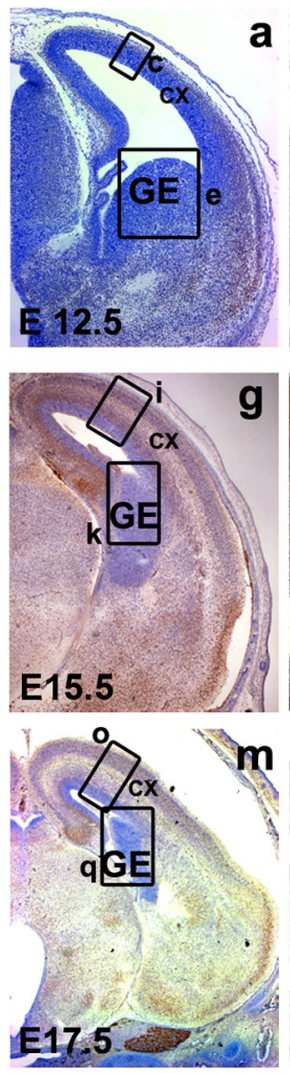

B

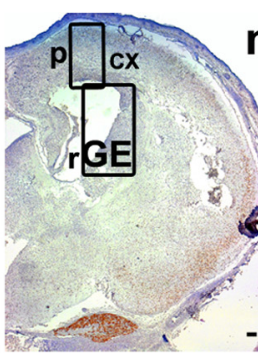

ADAM10 cKO

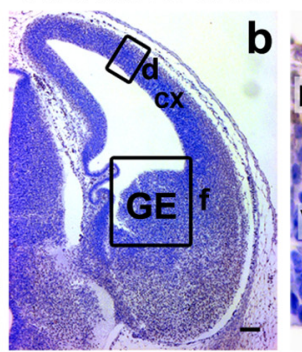

Control
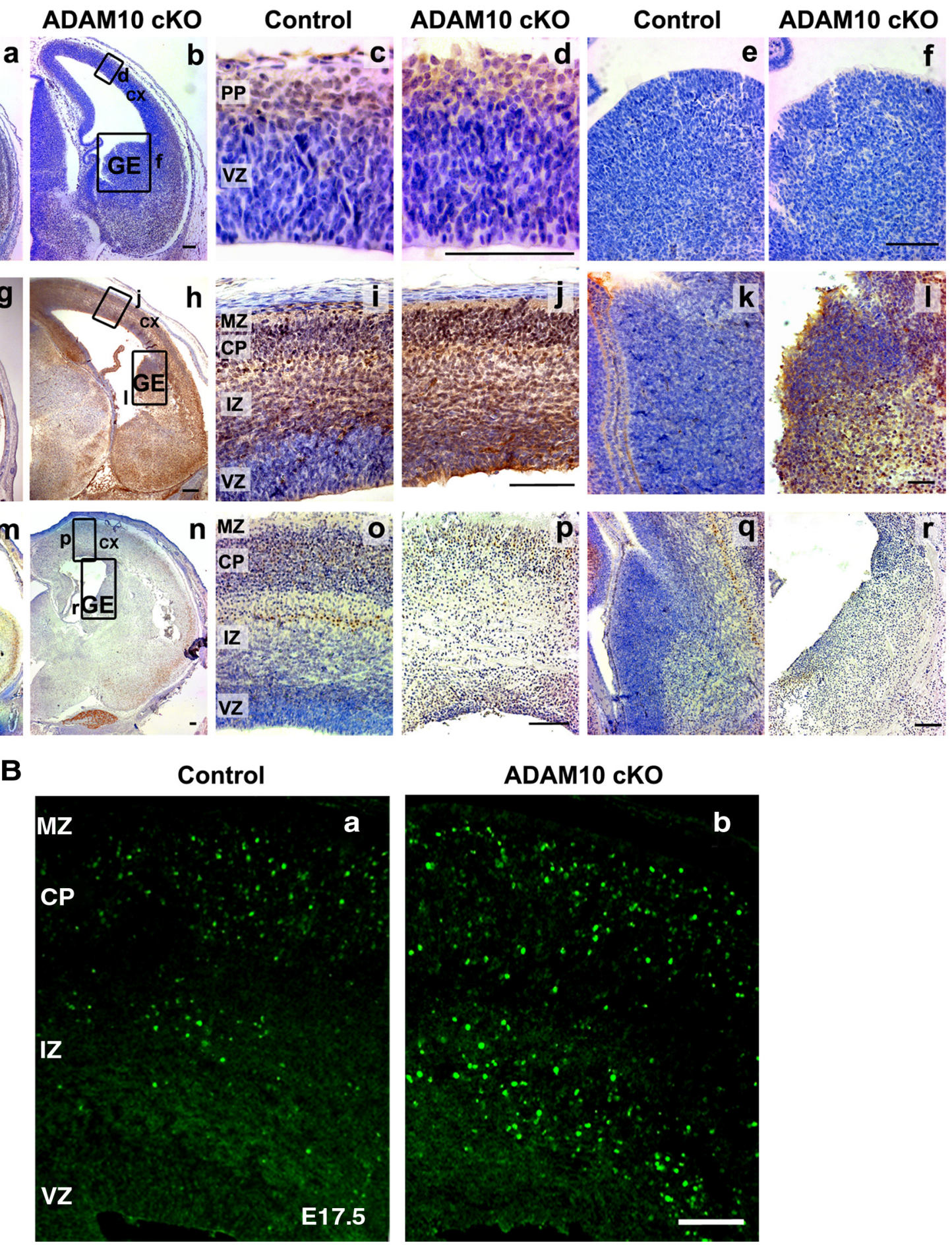

ADAM10 cKO

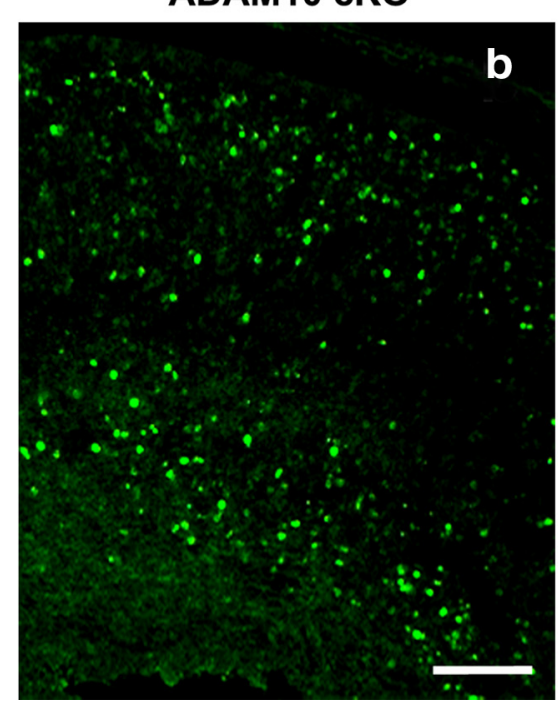

Figure 3. Increased neuronal differentiation and disrupted laminar organization of the cerebral cortex in Adam 10 cKO mice. $A$, Serial coronal brain sections for E12.5, E15.5, and E17.5 of Adam 10 cK0 and littermate controls were stained with a monoclonal antibody against $\operatorname{NeuN}(\boldsymbol{a}-\boldsymbol{f}) \cdot \boldsymbol{a}, \boldsymbol{b}$, At E12.5 the NeuN labeling patterns were the same in Adam 10 cK0 and control brains. $\boldsymbol{c}-\boldsymbol{f}$, Higher-power views of boxed areas in $\boldsymbol{a}$ and $\boldsymbol{b} . \boldsymbol{g}, \boldsymbol{h}$, At E15.5 more NeuN-positive neurons were present in the developing cortex in the Adam 10 CKO in the VZ and the GE. $\boldsymbol{i}-\boldsymbol{l}$, Higher-powerviews of boxed areas in $\boldsymbol{g}$ and $\boldsymbol{h} . \boldsymbol{m}, \boldsymbol{n}$, AtE17.5 there was less NeuN-positive staining in the Adam 10 cKO and it was distributed diffusely and was not arranged into well defined areas as in the control brain. $\boldsymbol{o}-\boldsymbol{r}$, Higher-power views of boxed areas in $\boldsymbol{m}$ and $\boldsymbol{n}$. Scale bars, $100 \mu \mathrm{m}$. B, BrdU birth dating revealed the determination of newly generated neurons labeled at E13.5 and collected at E17.5. Coronal sections of control and Adam $10 \mathrm{cKO}$ showed more intensely labeled neurons in the $\mathrm{Adam} 10 \mathrm{CKO}$ cortex (b), which were distributed more diffusely also in the IZ and not mainly into the well defined cortical plate (CP) as in the control brain (a). Scale bars, $100 \mu \mathrm{m}$.

cortical plate, whereas in the cKO more cells were scattered across the intermediate zone (Fig. $3 B a, B b$ ). These results indicated a role for ADAM10 in cortical layering and neuronal migration.

\section{Effect of ADAM10 deletion on neuronal proliferation}

The early neuronal differentiation could explain the cell loss observed in the Adam 10 cKO brains, but alternatively changes in proliferation or apoptosis had to be considered as well. We first immunolabeled sections from control and Adam10 cKO embryos with the cell cycle marker KI67 (Fig. 4). No difference in the number of KI67-positive proliferating cells in the Adam $10 \mathrm{cKO}$ and littermate control brains at E12.5 (Fig. $4 a-f$ ) was observed, showing that the lack of ADAM10 does not lead to a reduction in the proliferation rate of neural progenitor cells at early embry- 

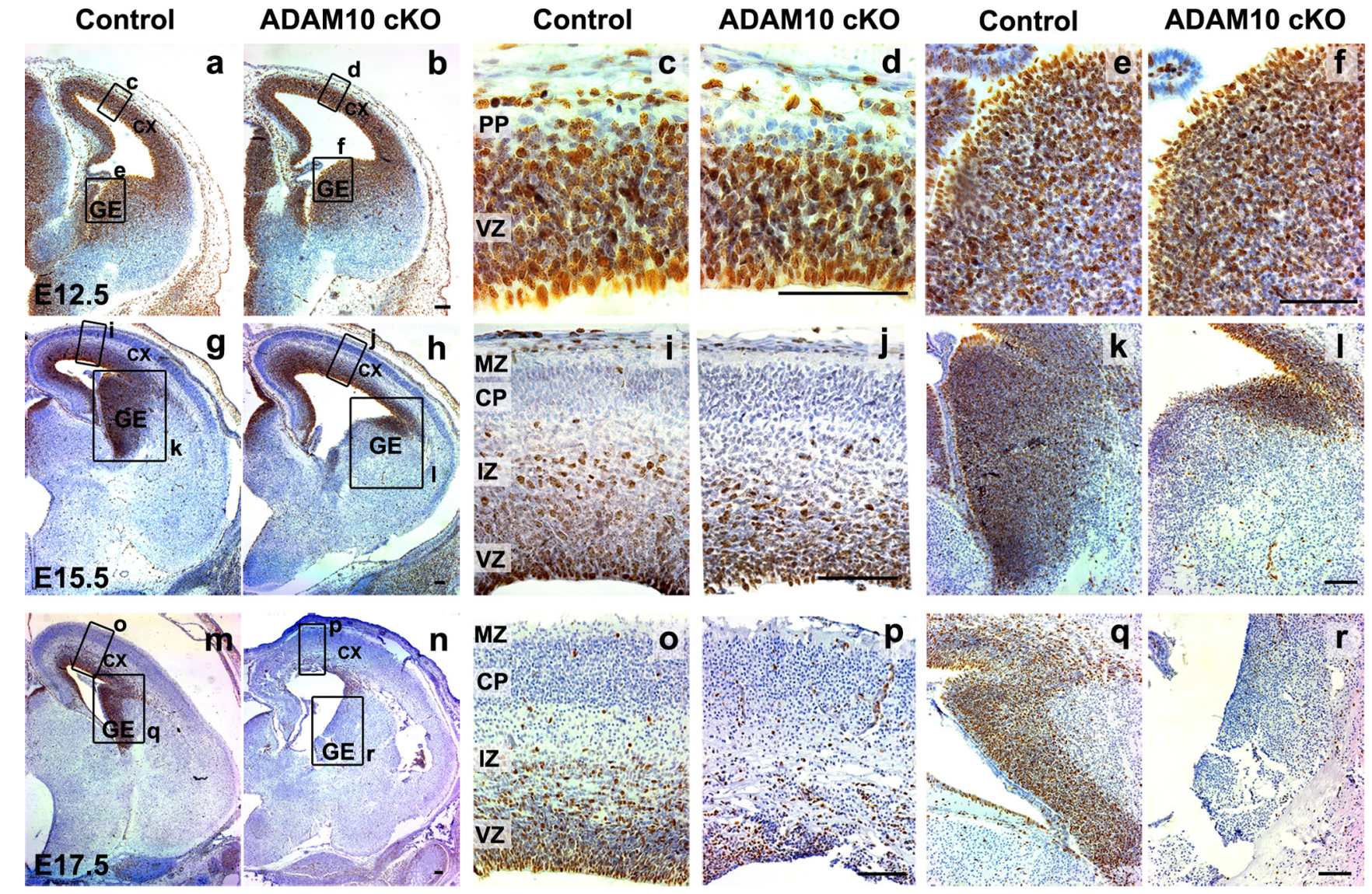

Figure 4. Comparison of proliferation in the Adam 10 CKO and littermate control brains. $\boldsymbol{a}-\boldsymbol{r}$, Comparable coronal sections of $A d a m 10$ cK0 and control at E12.5, E15.5, and E17.5 were stained with a monoclonal antibody against KI67. $\boldsymbol{a}, \boldsymbol{b}$, At E12.5 the KI67 staining pattern was unchanged in Adam 10 cK0 and control. c-f, Higher-power views, boxed in $\boldsymbol{a}$ and $\boldsymbol{b}$. $\boldsymbol{g}$, $\boldsymbol{h}$, At E15.5 the KI67 staining pattern was similar in the cortex, whereas the GE of the Adam 10 CKO contained fewer proliferating neurons than that of the control. $\boldsymbol{i}-\boldsymbol{I}$, Higher-power views, boxed in $\boldsymbol{g}$ and $\boldsymbol{h}$. $\boldsymbol{m}, \boldsymbol{n}$, At E17.5 the KI67 staining is less in both the cortex and the GE of the Adam 10 CKO. o-r, Higher-power views, boxed in $\boldsymbol{m}$ and $\boldsymbol{n}$. Scale bars, $100 \mu \mathrm{m}$.

onic age. However, at E15.5 the Adam10 cKO cortex displayed a minor and the GE a drastic decrease in the number of KI67positive cells (Fig. $4 g-l$ ), which corresponded to the increased number of NeuN-positive cells in Figure $3 A$ at the same embryonic age. By E17.5, considerably fewer KI67-positive cells remained in the ventricular zone of the cKO brains (Fig. $4 m-r$ ). We also performed staining for activated caspase- 3 on serial coronal brain sections at E12.5, E15.5, and E17.5 in Adam10 cKO and control brains (data not shown). A minor number of positive cells were observed in $\mathrm{cKO}$ and the control brains and although close observation suggested a slight increase in the number of apoptotic cells in the cortex and GE from cKO brains, this difference was not significant (Table S1, available at www.jneurosci.org as supplemental material), indicating that apoptosis is not the primary cause of cell loss in the E17.5 Adam10 cKO brains.

\section{Disrupted sphere organization in neurospheres derived from Adam 10 cKO embryos}

We examined the number of neural stem cells in the Adam10 cKO embryonic brain using the neurosphere assay (Reynolds et al., 1992; Tropepe et al., 1999). The ganglionic eminence from E13.5 Adam10 cKO embryos and their littermate controls were dissociated into single cells to generate neurospheres (Fig. 5A). The number of neural stem cells isolated from the E13.5 Adam10 cKO brains was decreased by $50 \%(p<0.01)$. In addition, an increased number of differentiated cells were attached to the flask compared with littermate controls (Fig. 5A). Single primary neu- rosphere colonies were capable of producing new secondary neurospheres after $5 \mathrm{~d}$ in vitro. The number of descendant secondary neurospheres generated from subcloning the single primary neurosphere can be used to estimate the extent to which the initial primary neurosphere from stem cells undergoes symmetric expansionary divisions (Reynolds and Weiss, 1996). The numbers of secondary neurosphere colonies from E13.5 Adam $10 \mathrm{cKO}$ and control were the same (data not shown). There was also no difference in the amount of KI67 proliferating cells or apoptotic cells within the neurospheres (Fig. $5 B c-B f, B m, B n, C$ ), suggesting that the remaining proliferating cells in the Adam $10 \mathrm{cKO}$ brains retained a normal proliferation capacity.

Each sphere represents a mixture of stem and early committed precursor cells (Campos et al., 2004). To examine the cellular composition and distribution inside the neurospheres, we cut paraffin sections of intact proliferating neurospheres and immunostained them with different antibodies (Fig. 5B). We then compared the distribution of stem cell markers (KI67, Nestin) (Fig. $5 B c, B e$ ) with markers of early committed precursor cells for neurons (doublecortin) (Fig. 5Bi) and astrocytes (GFAP) (Fig. 5Bg). $\mathrm{KI}_{6}{ }^{+}$and Nestin ${ }^{+}$cells were present around the edge of the sphere, whereas the differentiation markers were mainly present inside the sphere, demonstrating the separation of stem cell and early committed precursor populations in the neurospheres. This might reflect the situation in the developing nervous system, in which the proliferating stem cells in the ventricular zone form a distinct layer from the newly differentiated postmitotic neurons 
present in more superficial regions of the cortex. This was further illustrated by a separation of KI67 and NeuN expression in the control embryonic cortex as shown in Figures 3 and 4. The Adam10 cKO spheres displayed a disturbed organization, similar to the situation in vivo, suggesting that the neurosphere model is indeed a good model to investigate the function of ADAM10 in neuronal differentiation (Fig. $5 B a-B n$ ). Together, there were fewer neural stem cells in the Adam10 cKO brains, but the remaining proliferating cells were perfectly capable of proliferating and generating neurospheres in vitro, demonstrating their neuronal stem cell capacity.

\section{Cell fate decision between neurons and glial cells are mediated through ADAM10 activity}

To assess neural stem cell multipotentiality, secondary neurospheres as a whole or in single-cell suspensions were cultured on poly-L-ornithin-coated coverslips in the presence of $1 \%$ serum for $5 \mathrm{~d}$. The cells were immunostained for MAP2 (neurons), GFAP (astrocytes), and CNPase (oligodendrocytes) (Fig. 6A). The neurospheres derived from E13.5 Adam $10 \mathrm{cKO}$ neural stem cells gave rise to more neuronal progeny than those from control neural stem cells as demonstrated by the strong increase in MAP2-expressing cells. However, the increase in neurons occurred at the expense of the glial lineages as seen by the decreased number of $\mathrm{GFAP}^{+}$cells (Fig. 6Aa-Ad; schematized in Fig. 6C). No difference was observed in the number of oligodendrocytes, but it should be noted that they represented only a minor fraction of the total cell number (Fig. $6 A e, A f, B$ ). In addition, we saw a fourfold increase in the number of apoptotic cells in the Adam $10 \mathrm{cKO}$ when compared with control spheres (Fig. $6 A g, A h)(p<0.05)$.

\section{ADAM10 deletion causes reduced Notch signaling in vivo}

Notch activity has been shown to be important in cell fate decision during neurogenesis (Ishibashi et al., 1995; Schuurmans and Guillemot, 2002; Yoon et al., 2004; Alexson et al., 2006). To understand the molecular base of the premature neuronal differentiation in Adam 10 cKO embryos, we analyzed extracts from $\mathrm{P} 1$ brains from Adam $10 \mathrm{cKO}$ and controls for the presence of Notch-1 fragments (Fig. 6D). Using an antibody against the mouse Notch-1 Cdc10/ankyrin repeat cytokine response region, an accumulation of the furin-generated $\mathrm{S} 1$ Notch-1 cleavage product in the absence of ADAM10 was evident (Fig. 6D). In line with these observations, immunoblotting of Adam10 cKO brain extracts using an antibody directed against the cleaved intracellular (activated) form of the NICD also re-
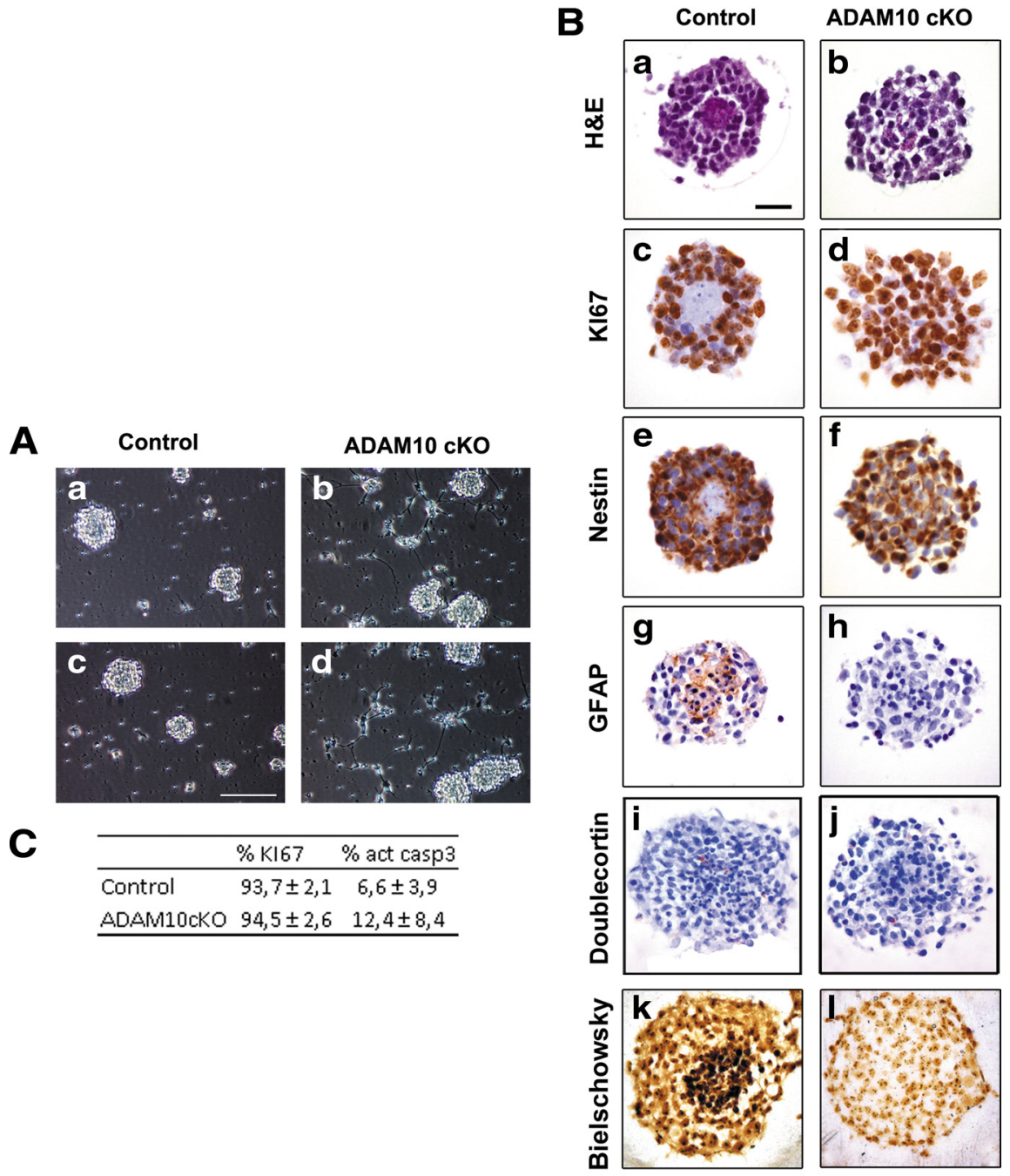

Figure 5. Neural stem cells are depleted in E13.5 Adam10 CKO ganglionic eminence and Adam10 mutant spheres have a disrupted sphere organization. $\boldsymbol{A}$, Neurospheres, which consist of neural stem cells, isolated from the ganglionic eminence of E13.5 control and $A d a m 10 \mathrm{CKO}$ brains at the day of plating are shown. There were more nonproliferating cells already attached to the surface of the culture flask in the $\mathrm{KO} O(\boldsymbol{b}, \boldsymbol{d})$ compared with the control $(\boldsymbol{a}, \boldsymbol{c})$. Scale bar, $50 \mu \mathrm{m}$. $\boldsymbol{B}$, Secondary neurosphere organization: Control neurospheres had an edge of dividing $\mathrm{KI}_{67}{ }^{+}$, Nestin ${ }^{+}$cells and a core of mainly early differentiated gfap ${ }^{+}$ ublecortin ${ }^{+}$cells, and Bielschowsky-stained cell processes $(\boldsymbol{c}, \boldsymbol{e}, \boldsymbol{g}, \boldsymbol{i}, \boldsymbol{k})$, while the Adam 10 cK0 spheres showed a disrupted organization $(\boldsymbol{d}, \boldsymbol{f}, \boldsymbol{h}, \boldsymbol{j}, \boldsymbol{I})$. However the apoptotic staining [activated caspase 3 (Act casp3)] pattern was the same in both mutant and control spheres $(\boldsymbol{m}, \boldsymbol{n})$. Scale bar, $20 \mu \mathrm{m}$. C, Quantitative estimation of $\boldsymbol{B}$ showing no differences in the amount of proliferating cells or apoptotic cells in the secondary Adam 10 cKO and control spheres.

vealed a strong reduction in the generation of NICD compared with $A$ dam $10^{F l / F l}$ brain extracts not expressing the Cre transgene (Fig. 6D).

To address the question whether the observed alteration in Notch-1 processing affects Notch-1-dependent signaling, we also investigated Hes 1, Hes5, Hey1, and Hey2 transcripts, which encode basic helix-loop-helix transcription factors, major downstream effectors of the Notch signaling pathway. Quantitative RT-PCR (qRT-PCR) of whole-brain extracts from newborns demonstrated significant reductions of $47,90,40$, and $49 \%$, respectively (Fig. 6E), indicating a downregulation of Notch signaling in the absence of ADAM10. 
A
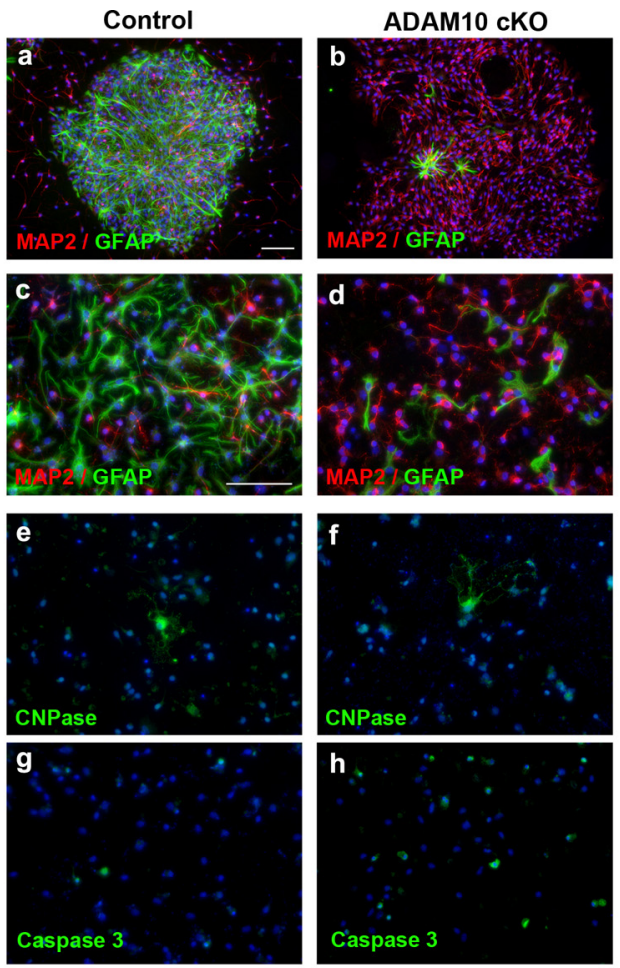

C
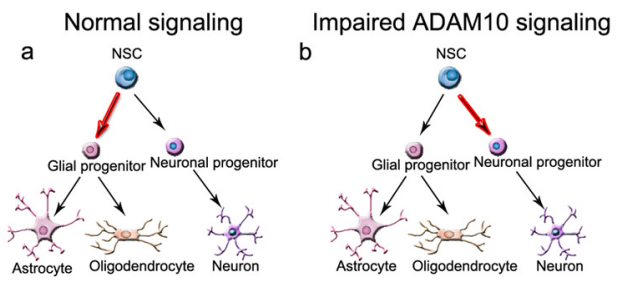

B

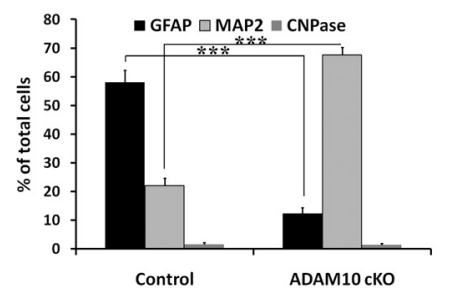

D
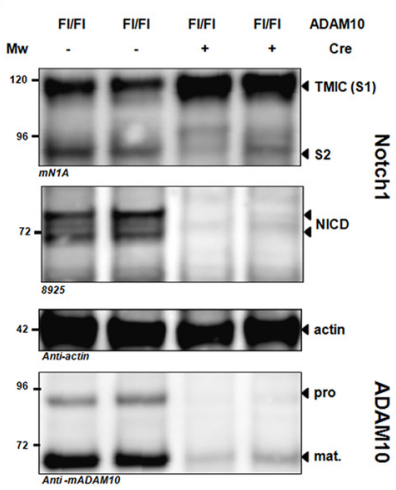

E

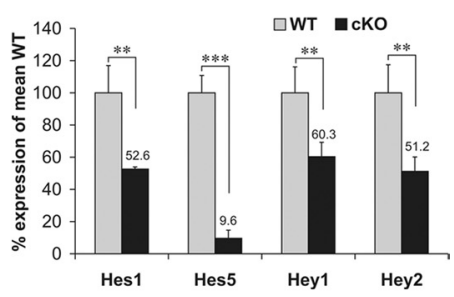

Figure 6. Adam 10 mutant spheres display an increase in neuronal differentiation at the expense of astrocytes due to a disturbed Notch-1 pathway. $\boldsymbol{A}$, Single primary neurospheres as a whole or in single cells from control and Adam 10 cKO brains were induced to differentiate and immunolabeled for neurons (MAP2), astrocytes (GFAP), oligodendrocytes (CNPase), and activated caspase-3 $(\boldsymbol{a}-\boldsymbol{h})$. Scale bar, $100 \mu \mathrm{m} . \boldsymbol{B}$, Greater percentages of neurons expressing MAP2 and fewer GFAP-positive cells were observed differentiating from Adam 10 CK0 spheres compared with control spheres ( $\left.{ }^{* * *} p<0.001\right)$. C, Schematic representation of the effects of ADAM10 in cell fate decision in the developing nervous system. NSC, Neural stem cell. D, A defect in the proteolytic processing of Notch-1 in Adam 10 cKO brains was demonstrated by immunoblotting P1 brain extracts from controls and Adam 10 cKOs. Immunoblotting with the anti-Notch-1 mN1A antibody shows an accumulation of an approximately $120 \mathrm{kDa}$ fragment (most likely the S1 furin cleavage product) and a decrease in the S2 Notch-1 fragment in Adam 10-deleted brains. Blotting with an antibody (8925) against the intracellular fragment of Notch-1 reveals a dramatic reduction in the generation of the NICD. Actin blotting shows equal loading. Using the same lysates, immunoblot analysis against mouse ADAM10 shows a strong reduction in Adam 10 expression in the cKO brains. TMIC, Transmembrane and intracellular domain (Furin cleavage on Notch1); pro, proform of ADAM10; mat, mature form of ADAM10. E, Downregulation of Notch-1 signaling in Adam 10 cK0 brain. qRT-PCR of Notch target genes Hes1, Hes5, Hey1, and Hey2. A strong reduction in the levels of Hes1, Hes5, Hey1, and Hey5 was found in the Adam10 CKO brain $\left.{ }^{* *} p<0.01,{ }^{* * *} p<0.001\right)$.

\section{ADAM10 contributes to APP processing in primary neurons} The generation of ADAM10-deficient neurons provided a unique opportunity to address the importance of ADAM10 in the physiologic constitutive processing of APP. To address this question, we analyzed the generation of APP cleavage products in primary neuronal cultures from E14.5 Adam $10 \mathrm{cKO}$ embryos compared with controls. The APP ectodomain $(\operatorname{sAPP} \alpha, \operatorname{sAPP} \beta)$, full length (APP-FL), membrane-bound CTF (APP-CTF $\alpha$, APP-CTF $\beta$ ), and total $\mathrm{A} \beta$ were analyzed from supernatants and cell extracts of dissociated neurons (Fig. 7). Together, the diminished appearance of the membrane-bound $\alpha$-secretase-cleaved APP CTF $(\mathrm{CTF} \alpha)$, and the observed $90 \%$ reduction in the levels of secreted sAPP $\alpha$ indicate that ADAM10 is the most important APP $\alpha$-secretase in these neurons. Surprisingly, we also observed a paradoxical reduction in $\operatorname{CTF} \beta, \operatorname{sAPP} \beta$, and total $\mathrm{A} \beta$ peptide production and in the amount of $\mathrm{A} \beta_{1-40}$ and $\mathrm{A} \beta_{1-42}$ in the Adam $10 \mathrm{cKO}$ (Fig. $7 A, B$ ). Comparison of the $\mathrm{A} \beta$ spectra between control and Adam10 cKO showed no shift toward longer $\mathrm{A} \beta$ peptide species $\left(\mathrm{A} \beta_{1-42}\right)$ or shorter $\mathrm{A} \beta$ peptides $\left(\mathrm{A} \beta_{1-37}, \mathrm{~A} \beta_{1-38}, \mathrm{~A} \beta_{1-40}\right)$ but confirmed the general decrease in all the $A \beta$ species in the $\mathrm{cKO}$ (Fig. 7C,D).

\section{Discussion}

In this manuscript, we demonstrate the crucial role of ADAM10 in neuronal differentiation and the establishment of the cerebral cortex. Furthermore, we provide evidence for its essential role in Notch signaling and in the physiological $\alpha$-secretase processing of APP in neurons.

Using a CNS-specific Nestin-Cre mouse, which expresses Cre-recombinase in the NPC (Zimmerman et al., 1994), we were able to circumvent the previously documented early embryonic lethality of Adam10 KO mice (Fig. 1 and Table 1). Nevertheless, CNS organization was severely affected in these embryos, leading to massive intracranial bleedings and complete disorganization of the cortical layering of the brain (Fig. 2). Detailed histological analyses of the Adam10 cKO brain showed an increased number of postmitotic neurons revealed by $\mathrm{NeuN}$ staining (Fig. $3 A$ ) and a reduced number of KI67-positive progenitor cells (Fig. 4). Thus, lack of ADAM10 causes a premature differentiation of neural progenitor cells into postmitotic neurons, resulting in a partial depletion of the neural progenitor population, which also explains the small GE. These studies were further confirmed with the neurosphere assay, which indicates that more mature neurons are already obtained when plating cells from ADAM10-deficient brains (Fig. 5). The relative depletion of neurons was not associated with increased activated caspase-3 staining, showing that loss of ADAM10 does not result in massive apoptotic cell death at early stages (Table S1, available at www. jneurosci.org as supplemental material), ruling out the possibility of apoptosis as the primary cause of neuronal cell loss.

The effect of ADAM10, as would be predicted for a premature differentiation phenotype, is not observed in the neuronal progenitor cells per se. Although fewer progenitors are present in the plating assay (Fig. 5), they remain fully capable of generating neurons and glia cells (Fig. 6). This was also further confirmed in vivo as KI67-positive, proliferating cells were equally present in Adam $10 \mathrm{cKO}$ and control brains at an early developmental age, E12.5 (Fig. 4). Thus, ADAM10 is not involved in the regulation of the early neural progenitor proliferation. Our H\&E stainings (Fig. 2) revealed a disruption of the cortical layering and BrdU cell birth dating analyses showed an apparent defect in neuronal 
migration in the Adam $10 \mathrm{cKO}$, with neurons arriving in ectopic sites (Fig. 3). This suggests a role for ADAM10 in the regulation of the neuronal migration during cortical development.

The Notch signaling pathway is known to play a fundamental role in cell fate decisions in the development of the nervous system at many different levels. (ArtavanisTsakonas et al., 1999). Notch signals govern the decision between neuronal (in an inhibitory fashion) and glial lineages (promoting this fate), modulate the fate of terminally differentiated neurons, and affect neuronal migration and even learning and memory (Yu et al., 2001; Costa et al., 2003; Saura et al., 2004; Wang et al., 2004; Louvi and Artavanis-Tsakonas, 2006; Corbin et al., 2008; Hashimoto-Torii et al., 2008). In addition, Notch pathway components, including ligands, receptors, modulators, and targets, are expressed in the telencephalic ventricular zone (Lindsell et al., 1996; Zhong et al., 1997; Irvin et al., 2001; Yun et al., 2002). Mouse mutants deficient in genes of the Notch signaling pathway support the view that this pathway plays a critical role in regulating the neural progenitor pool during neocortical development (ArtavanisTsakonas et al., 1999; Hitoshi et al., 2002; Yoon et al., 2004; Mizutani and Saito, 2005; Yoon and Gaiano, 2005; Gaiano, 2008). Conditional deletion of Notch-1 in the neural progenitor pool, similar to the strategy used for the ADAM10 deletion reported here, indeed resulted in precocious neuronal differentiation (Yang et al., 2004). A similar phenotype was also found in Nestin-Cre transgenedriven inactivation of presenilin (PS) (Kim and Shen, 2008), which is known to mediate the Notch-1 S3 cleavage and NICD production (De Strooper et al., 1998, 1999). Both the Adam10 conditional knock-out presented here and the PS inactivation in NPCs and NPC-derived neurons and glia show that both Notch signaling proteases are required for neural progenitor cells to re-enter cell cycle and for the expansion of neural progenitor population during embryonic development. The depletion of progenitor cells may indeed also lead to a reduced number of astrocytes, which are involved in the formation of the blood-brain barrier, thereby contributing to the hemorrhages observed in presenilin (PS) cKO mice (Kim and Shen, 2008) and Adam10 conditional knock-out mice (this study).

To understand the molecular mechanism underlying the premature neuronal differentiation observed in Adam $10 \mathrm{cKO}$ brain, we examined the proteolytic processing of Notch-1 as well as the expression of Notch-1 target genes Hes 1 and Hes5 and Hey1 and Hey2, which are basic helix-loop-helix transcriptional regulators that antagonize proneural genes like Mash1 and Neurogenins. This antagonism blocks early neuronal gene expression and is central to the inhibition of neuronal differentiation by Notch-1 signaling. By qRT-PCR, we found a clear reduction in the mRNA expression of Hes1 and Hes5 and Hey1 and Hey2 target genes, further proving the important role of ADAM10 in the regulation of the Notch signaling (Fig. $6 E$ ).

Whereas in Drosophila, the ADAM10 ortholog Kuzbanian has been amply demonstrated to act as Notch sheddase, in the mammalian system, cell-based assays have in contrast implicated
B

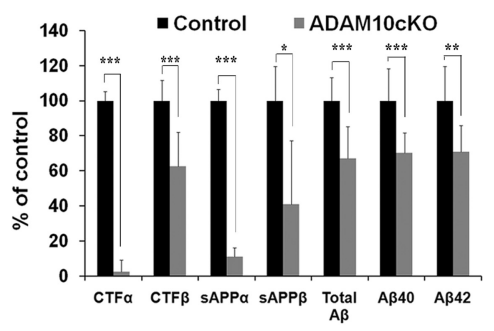

D

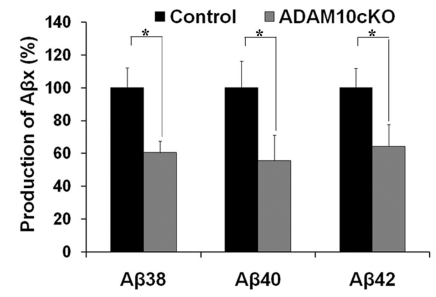

Figure 7. APP $\alpha$ processing is severely reduced in neurons derived from E14.5 Adam 10 cK0 embryos. $A, C$, Primary neurons were with recombinant Semliki Forest Virus driving expression of human wild-type APP. Antibody B63 recognizing the 20

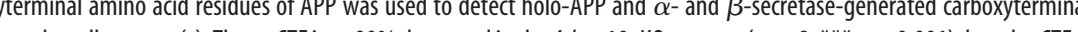

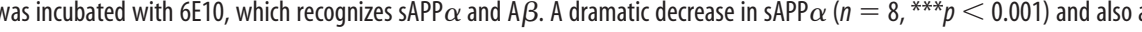
作 $10 \mathrm{CKO}$ were measured and normalized to the level of expression of APP holoprotein. A significant reduction quantification in $\boldsymbol{D}\left(n=3,{ }^{*} p<0.05\right)$.

mainly ADAM17 in the S2 Notch-1 cleavage (Brou et al., 2000; Mumm et al., 2000). The Notch-like phenotype of classical Adam10-deficient mice (Hartmann et al., 2002), the novel data in the current work showing a direct effect of ADAM10 on the ability to generate signal-relevant Notch intracellular domain (Fig. $6 D$ ), and the lack of Notch-related alterations in Adam17deficient mice (Peschon et al., 1998), clearly underline the essential role of ADAM10 as the Notch sheddase in vivo also in mammalian species. Although the phenotype of our cKO mice clearly highlights the role of the ADAM10 in Notch-1 signaling, we cannot completely exclude the possibility that part of the abnormalities may be explained by a reduced shedding of additional neuronal surface molecules. In this regard, it is interesting to note that in ADAM10-deficient neurons the CTF1 generation of $\mathrm{N}$-cadherin was severely reduced (Fig. S1, available at www. jneurosci.org as supplemental material), confirming our earlier data (Reiss et al., 2005) in fibroblast cells. We also cannot rule out the possibility that the decreased level of sAPP $\alpha$ contributes to the alteration in neural progenitor cell proliferation/differentiation in our Adam 10 cKO phenotype, as previous studies have shown that $\operatorname{sAP} \alpha$ is a neurotrophic factor that affects the development of embryonic brain cells, including progenitor cells. sAPP $\alpha$ has also been suggested to play a role in developmental and synaptic plasticity in the nervous system (Mattson, 1994; Furukawa et al., 1996; Caillé et al., 2004; Rohe et al., 2008).

We finally focused on the processing of one of the most medically important putative ADAM10 substrates, i.e., APP. We provide here convincing evidence that loss of ADAM10 disturbs the $\alpha$-secretase-mediated cleavage of APP to a large extent, indicating that ADAM10 is the major $\alpha$-secretase in the cells that are most relevant to Alzheimer's disease (Fig. 7). Our work agrees 
with previous overexpression experiments in mice and in cellbased systems (Postina et al., 2004; Postina, 2008). Although it is possible that the other $\alpha$-secretase candidates, including ADAM9 and ADAM17, also contribute to a certain extent to APP processing in neurons, their contribution appears to be quantitatively much less significant. Surprisingly, we found in the ADAM10 KO neurons a paradoxical significant reduction in the $\beta$-secretase cleavage, which is in contradiction to the general dogma that BACE1 and $\alpha$-secretase are in competition for ectodomain cleavage of APP (Skovronsky et al., 2000). This concept is supported by a number of observations; for instance, several pharmacological agents known to stimulate $\alpha$-secretase cleavage of APP also reduce $\beta$-cleavage, thereby reducing $A \beta$ peptide generation (Allinson et al., 2003). Likewise, overexpression of ADAM10 in an Alzheimer's disease mouse model decreases $A \beta$ plaque load and cognitive deficits (Postina et al., 2004), while BACE1 reduction results in an elevation of $\alpha$ - and a decrease of $\beta$-cleavage (Vassar et al., 1999). The molecular basis of this competition between the two secretase pathways is not very well understood and could involve as well direct competition between the two proteases for the substrate, as effects on subcellular trafficking of substrate or protease. In our experiments, in which ADAM10 is taken away in primary neurons, we see an opposite effect, i.e., a decrease in $\beta$-secretase activity [although $\beta$-secretase levels are not decreased (results not shown)]. We speculate that ADAM10 deficiency and the effects on APP processing result in a change in localization or subcellular trafficking of either BACE1 or APP, but further research is clearly needed to explain this intriguing phenomenon.

In conclusion, we present the first characterization of neuronspecific Adam10-deficient mice and provide substantial evidence for the key function of ADAM10 in neural Notch signaling, in Notchdependent CNS development, and in neuronal $\alpha$-secretase processing of APP, with implications for Alzheimer's disease.

\section{References}

Alexson TO, Hitoshi S, Coles BL, Bernstein A, van der Kooy D (2006) Notch signaling is required to maintain all neural stem cell populations-irrespective of spatial or temporal niche. Dev Neurosci 28:34-48.

Allinson TM, Parkin ET, Turner AJ, Hooper NM (2003) ADAMs family members as amyloid precursor protein alpha-secretases. J Neurosci Res $74: 342-352$

Angevine JB Jr, Sidman RL (1961) Autoradiographic study of cell migration during histogenesis of cerebral cortex in the mouse. Nature 192:766-768.

Annaert WG, Levesque L, Craessaerts K, Dierinck I, Snellings G, Westaway D, George-Hyslop PS, Cordell B, Fraser P, De Strooper B (1999) Presenilin 1 controls gamma-secretase processing of amyloid precursor protein in pre-golgi compartments of hippocampal neurons. J Cell Biol 147:277-294.

Artavanis-Tsakonas S, Rand MD, Lake RJ (1999) Notch signaling: cell fate control and signal integration in development. Science 284:770-776.

Asai M, Hattori C, Szabó B, Sasagawa N, Maruyama K, Tanuma S, Ishiura S (2003) Putative function of ADAM9, ADAM10, and ADAM17 as APP alpha-secretase. Biochem Biophys Res Commun 301:231-235.

Bozkulak EC, Weinmaster G (2009) Selective use of Adam10 and Adam17 in activation of Notch1 signaling. Mol Cell Biol 29:5679-5695.

Brou C, Logeat F, Gupta N, Bessia C, LeBail O, Doedens JR, Cumano A, Roux P, Black RA, Israël A (2000) A novel proteolytic cleavage involved in Notch signaling: the role of the disintegrin-metalloprotease TACE. Mol Cell 5:207-216.

Buxbaum JD, Liu KN, Luo Y, Slack JL, Stocking KL, Peschon JJ, Johnson RS, Castner BJ, Cerretti DP, Black RA (1998) Evidence that tumor necrosis factor alpha converting enzyme is involved in regulated alpha-secretase cleavage of the Alzheimer amyloid protein precursor. J Biol Chem 273:27765-27767.

Caillé I, Allinquant B, Dupont E, Bouillot C, Langer A, Müller U, Prochiantz A (2004) Soluble form of amyloid precursor protein regulates prolifer- ation of progenitors in the adult subventricular zone. Development 131:2173-2181.

Campos LS, Leone DP, Relvas JB, Brakebusch C, Fässler R, Suter U, ffrenchConstant C (2004) Betal integrins activate a MAPK signalling pathway in neural stem cells that contributes to their maintenance. Development 131:3433-3444.

Caviness VS Jr, Takahashi T, Nowakowski RS (1995) Numbers, time and neocortical neuronogenesis: a general developmental and evolutionary model. Trends Neurosci 18:379-383.

Corbin JG, Gaiano N, Juliano SL, Poluch S, Stancik E, Haydar TF (2008) Regulation of neural progenitor cell development in the nervous system. J Neurochem 106:2272-2287.

Costa RM, Honjo T, Silva AJ (2003) Learning and memory deficits in Notch mutant mice. Curr Biol 13:1348-1354.

De Strooper B, Saftig P, Craessaerts K, Vanderstichele H, Guhde G, Annaert W, Von Figura K, Van Leuven F (1998) Deficiency of presenilin-1 inhibits the normal cleavage of amyloid precursor protein. Nature 391:387-390.

De Strooper B, Annaert W, Cupers P, Saftig P, Craessaerts K, Mumm JS, Schroeter EH, Schrijvers V, Wolfe MS, Ray WJ, Goate A, Kopan R (1999) A presenilin-1-dependent gamma-secretase-like protease mediates release of Notch intracellular domain. Nature 398:518-522.

Furukawa K, Barger SW, Blalock EM, Mattson MP (1996) Activation of K+ channels and suppression of neuronal activity by secreted beta-amyloidprecursor protein. Nature 379:74-78.

Gaiano N (2008) Strange bedfellows: Reelin and Notch signaling interact to regulate cell migration in the developing neocortex. Neuron 60:189-191.

Gordon WR, Arnett KL, Blacklow SC (2008) The molecular logic of Notch signaling-a structural and biochemical perspective. J Cell Sci 121:3109-3119.

Graus-Porta D, Blaess S, Senften M, Littlewood-Evans A, Damsky C, Huang Z, Orban P, Klein R, Schittny JC, Müller U (2001) Betal-class integrins regulate the development of laminae and folia in the cerebral and cerebellar cortex. Neuron 31:367-379.

Gutwein P, Mechtersheimer S, Riedle S, Stoeck A, Gast D, Joumaa S, Zentgraf H, Fogel M, Altevogt DP (2003) ADAM10-mediated cleavage of L1 adhesion molecule at the cell surface and in released membrane vesicles. FASEB J 17:292-294.

Hartmann D, de Strooper B, Serneels L, Craessaerts K, Herreman A, Annaert W, Umans L, Lübke T, Lena Illert A, von Figura K, Saftig P (2002) The disintegrin/metalloprotease ADAM 10 is essential for Notch signalling but not for alpha-secretase activity in fibroblasts. Hum Mol Genet 11:2615-2624.

Hashimoto-Torii K, Torii M, Sarkisian MR, Bartley CM, Shen J, Radtke F, Gridley T, Sestan N, Rakic P (2008) Interaction between Reelin and Notch signaling regulates neuronal migration in the cerebral cortex. Neuron 60:273-284.

Hatten ME (1990) Riding the glial monorail: a common mechanism for glial-guided neuronal migration in different regions of the developing mammalian brain. Trends Neurosci 13:179-184.

Hatten ME (1993) The role of migration in central nervous system neuronal development. Curr Opin Neurobiol 3:38-44.

Hattori M, Osterfield M, Flanagan JG (2000) Regulated cleavage of a contact-mediated axon repellent. Science 289:1360-1365.

Hinkle CL, Diestel S, Lieberman J, Maness PF (2006) Metalloproteaseinduced ectodomain shedding of neural cell adhesion molecule (NCAM). J Neurobiol 66:1378-1395.

Hitoshi S, Alexson T, Tropepe V, Donoviel D, Elia AJ, Nye JS, Conlon RA, Mak TW, Bernstein A, van der Kooy D (2002) Notch pathway molecules are essential for the maintenance, but not the generation, of mammalian neural stem cells. Genes Dev 16:846-858.

Hooper NM, Turner AJ (2002) The search for alpha-secretase and its potential as a therapeutic approach to Alzheimer s disease. Curr Med Chem 9:1107-1119.

Irvin DK, Zurcher SD, Nguyen T, Weinmaster G, Kornblum HI (2001) Expression patterns of Notch1, Notch2, and Notch3 suggest multiple functional roles for the Notch-DSL signaling system during brain development. J Comp Neurol 436:167-181.

Ishibashi M, Ang SL, Shiota K, Nakanishi S, Kageyama R, Guillemot F (1995) Targeted disruption of mammalian hairy and Enhancer of split homolog-1 (HES-1) leads to up-regulation of neural helix-loop- 
helix factors, premature neurogenesis, and severe neural tube defects. Genes Dev 9:3136-3148.

Janes PW, Saha N, Barton WA, Kolev MV, Wimmer-Kleikamp SH, Nievergall E, Blobel CP, Himanen JP, Lackmann M, Nikolov DB (2005) Adam meets Eph: an ADAM substrate recognition module acts as a molecular switch for ephrin cleavage in trans. Cell 123:291-304.

Kim WY, Shen J (2008) Presenilins are required for maintenance of neural stem cells in the developing brain. Mol Neurodegener 3:2.

Lieber T, Kidd S, Young MW (2002) Kuzbanian-mediated cleavage of Drosophila Notch. Genes Dev 16:209-221.

Lin J, Luo J, Redies C (2008) Differential expression of five members of the ADAM family in the developing chicken brain. Neuroscience 157:360-375.

Lindsell CE, Boulter J, diSibio G, Gossler A, Weinmaster G (1996) Expression patterns of Jagged, Delta1, Notch1, Notch2, and Notch3 genes identify ligand-receptor pairs that may function in neural development. Mol Cell Neurosci 8:14-27.

Louvi A, Artavanis-Tsakonas S (2006) Notch signalling in vertebrate neural development. Nat Rev Neurosci 7:93-102.

Mathews PM, Jiang Y, Schmidt SD, Grbovic OM, Mercken M, Nixon RA (2002) Calpain activity regulates the cell surface distribution of amyloid precursor protein. Inhibition of calpains enhances endosomal generation of betacleaved C-terminal APP fragments. J Biol Chem 277:36415-36424.

Mattson MP (1994) Secreted forms of beta-amyloid precursor protein modulate dendrite outgrowth and calcium responses to glutamate in cultured embryonic hippocampal neurons. J Neurobiol 25:439-450.

McConnell SK (1995) Constructing the cerebral cortex: neurogenesis and fate determination. Neuron 15:761-768.

Mission JP, Takahashi T, Caviness VS Jr (1991) Ontogeny of radial and other astroglial cells in murine cerebral cortex. Glia 4:138-148.

Mizutani K, Saito T (2005) Progenitors resume generating neurons after temporary inhibition of neurogenesis by Notch activation in the mammalian cerebral cortex. Development 132:1295-1304.

Mumm JS, Kopan R (2000) Notch signaling: from the outside in. Dev Biol 228:151-165.

Mumm JS, Schroeter EH, Saxena MT, Griesemer A, Tian X, Pan DJ, Ray WJ, Kopan R (2000) A ligand-induced extracellular cleavage regulates gammasecretase-like proteolytic activation of Notch1. Mol Cell 5:197-206.

Pan D, Rubin GM (1997) Kuzbanian controls proteolytic processing of Notch and mediates lateral inhibition during Drosophila and vertebrate neurogenesis. Cell 90:271-280.

Peschon JJ, Slack JL, Reddy P, Stocking KL, Sunnarborg SW, Lee DC, Russell WE, Castner BJ, Johnson RS, Fitzner JN, Boyce RW, Nelson N, Kozlosky CJ, Wolfson MF, Rauch CT, Cerretti DP, Paxton RJ, March CJ, Black RA (1998) An essential role for ectodomain shedding in mammalian development. Science 282:1281-1284.

Postina R (2008) A closer look at alpha-secretase. Curr Alzheimer Res 5:179-186.

Postina R, Schroeder A, Dewachter I, Bohl J, Schmitt U, Kojro E, Prinzen C, Endres K, Hiemke C, Blessing M, Flamez P, Dequenne A, Godaux E, van Leuven F, Fahrenholz F (2004) A disintegrin-metalloproteinase prevents amyloid plaque formation and hippocampal defects in an Alzheimer disease mouse model. J Clin Invest 113:1456-1464.

Rakic P (1988) Specification of cerebral cortical areas. Science 241:170-176.

Reiss K, Maretzky T, Ludwig A, Tousseyn T, de Strooper B, Hartmann D, Saftig P (2005) ADAM10 cleavage of N-cadherin and regulation of cellcell adhesion and beta-catenin nuclear signalling. EMBO J 24:742-752.

Reynolds BA, Weiss S (1996) Clonal and population analyses demonstrate that an EGF-responsive mammalian embryonic CNS precursor is a stem cell. Dev Biol 175:1-13.

Reynolds BA, Tetzlaff W, Weiss S (1992) A multipotent EGF-responsive striatal embryonic progenitor cell produces neurons and astrocytes. J Neurosci 12:4565-4574.

Rohe M, Carlo AS, Breyhan H, Sporbert A, Militz D, Schmidt V, Wozny C, Harmeier A, Erdmann B, Bales KR, Wolf S, Kempermann G, Paul SM, Schmitz D, Bayer TA, Willnow TE, Andersen OM (2008) Sortilinrelated receptor with A-type repeats (SORLA) affects the amyloid precursor protein-dependent stimulation of ERK signaling and adult neurogenesis. J Biol Chem 283:14826-14834.
Saura CA, Choi SY, Beglopoulos V, Malkani S, Zhang D, Shankaranarayana Rao BS, Chattarji S, Kelleher RJ 3rd, Kandel ER, Duff K, Kirkwood A, Shen J (2004) Loss of presenilin function causes impairments of memory and synaptic plasticity followed by age-dependent neurodegeneration. Neuron 42:23-36.

Schuurmans C, Guillemot F (2002) Molecular mechanisms underlying cell fate specification in the developing telencephalon. Curr Opin Neurobiol $12: 26-34$

Skovronsky DM, Moore DB, Milla ME, Doms RW, Lee VM (2000) Protein kinase C-dependent alpha-secretase competes with beta-secretase for cleavage of amyloid-beta precursor protein in the trans-golgi network. J Biol Chem 275:2568-2575.

Tronche F, Kellendonk C, Kretz O, Gass P, Anlag K, Orban PC, Bock R, Klein R, Schütz G (1999) Disruption of the glucocorticoid receptor gene in the nervous system results in reduced anxiety. Nat Genet 23:99-103.

Tropepe V, Sibilia M, Ciruna BG, Rossant J, Wagner EF, van der Kooy D (1999) Distinct neural stem cells proliferate in response to EGF and FGF in the developing mouse telencephalon. Dev Biol 208:166-188.

Vandermeeren M, Geraerts M, Pype S, Dillen L, Van Hove C, Mercken M (2001) The functional gamma-secretase inhibitor prevents production of amyloid beta 1-34 in human and murine cell lines. Neurosci Lett 315:145-148.

van Tetering G, van Diest P, Verlaan I, van der Wall E, Kopan R, Vooijs M (2009) The metalloprotease ADAM10 is required for notch1 S2 cleavage. J Biol Chem 284:31018-31027.

Vassar R, Bennett BD, Babu-Khan S, Kahn S, Mendiaz EA, Denis P, Teplow DB, Ross S, Amarante P, Loeloff R, Luo Y, Fisher S, Fuller J, Edenson S, Lile J, Jarosinski MA, Biere AL, Curran E, Burgess T, Louis JC, et al. (1999) Beta-secretase cleavage of Alzheimer's amyloid precursor protein by the transmembrane aspartic protease BACE. Science 286:735-741.

Vincent B (2004) ADAM proteases: protective role in Alzheimer's and prion diseases? Curr Alzheimer Res 1:165-174.

Wang Y, Chan SL, Miele L, Yao PJ, Mackes J, Ingram DK, Mattson MP, Furukawa K (2004) Involvement of Notch signaling in hippocampal synaptic plasticity. Proc Natl Acad Sci U S A 101:9458-9462.

Wen C, Metzstein MM, Greenwald I (1997) SUP-17, a Caenorhabditis elegans ADAM protein related to Drosophila KUZBANIAN, and its role in LIN-12/NOTCH signalling. Development 124:4759-4767.

Wiltfang J, Esselmann H, Bibl M, Smirnov A, Otto M, Paul S, Schmidt B, Klafki HW, Maler M, Dyrks T, Bienert M, Beyermann M, Rüther E, Kornhuber J (2002) Highly conserved and disease-specific patterns of carboxyterminally truncated Abeta peptides 1-37/38/39 in addition to 1-40/42 in Alzheimer's disease and in patients with chronic neuroinflammation. J Neurochem 81:481-496.

Yang X, Klein R, Tian X, Cheng HT, Kopan R, Shen J (2004) Notch activation induces apoptosis in neural progenitor cells through a p53dependent pathway. Dev Biol 269:81-94.

Yoon K, Gaiano N (2005) Notch signaling in the mammalian central nervous system: insights from mouse mutants. Nat Neurosci 8:709-715.

Yoon K, Nery S, Rutlin ML, Radtke F, Fishell G, Gaiano N (2004) Fibroblast growth factor receptor signaling promotes radial glial identity and interacts with Notch1 signaling in telencephalic progenitors. J Neurosci 24:9497-9506.

Yu H, Saura CA, Choi SY, Sun LD, Yang X, Handler M, Kawarabayashi T, Younkin L, Fedeles B, Wilson MA, Younkin S, Kandel ER, Kirkwood A, Shen J (2001) APP processing and synaptic plasticity in presenilin-1 conditional knockout mice. Neuron 31:713-726.

Yun K, Fischman S, Johnson J, Hrabe de Angelis M, Weinmaster G, Rubenstein JL (2002) Modulation of the notch signaling by Mash1 and Dlx $1 / 2$ regulates sequential specification and differentiation of progenitor cell types in the subcortical telencephalon. Development 129:5029-5040.

Zhong W, Jiang MM, Weinmaster G, Jan LY, Jan YN (1997) Differential expression of mammalian Numb, Numblike and Notch1 suggests distinct roles during mouse cortical neurogenesis. Development 124:1887-1897.

Zimmerman L, Parr B, Lendahl U, Cunningham M, McKay R, Gavin B, Mann J, Vassileva G, McMahon A (1994) Independent regulatory elements in the nestin gene direct transgene expression to neural stem cells or muscle precursors. Neuron 12:11-24. 